\title{
Bektaşî Babaları ve Diğer Tekkelerde Bektaşîleşmeye Dair Revnakoğlu Dosyalarından Tespitler
}

\section{Determinations in Revnakoğlu's Documents Regarding Bektashization among Bektashi Fathers and Other Dervish Lodges}

\author{
Mustafa $\operatorname{Koç}^{1}$ (D)
}

'Prof. Dr., İstinye Üniversitesi, Fen Edebiyat Fakültesi, Türk Dili ve Edebiyatı, İstanbul, Türkiye

ORCID: M.K. 0000-0002-9480-328X

Sorumlu yazar/Corresponding author: Mustafa Koç,

İstinye Üniversitesi, Fen Edebiyat Fakültesi, Türk Dili ve Edebiyatı, İstanbul, Türkiye

E-mail: mustafa.koc@istinye.edu.tr

Başvuru/Submitted: 27.04.2021

Kabul/Accepted: 18.05 .202

\section{Atıf/Citation:}

Koc, M. (2021). Bektaşî babaları ve diğer tekkelerde bektaşileşmeye dair revnakoğlu dosyalarından tespitler. TUDED, 61(1), 379-409. https://doi.org/10.26650/TUDED2020-928660

\section{ÖZET}

İstanbul tekke ve tarikat tarihi hakkında mühim araștırmalar yapan Cemalettin Server Revnakoğlu, aynı zamanda konuyla ilgili pek çok vesika ve eşyadan oluşan geniş bir arşiv meydana getirmiştir. Arşivinde Bektaşîlikle ilgili pek çok vesika dağınık halde bulunmaktadır ve neşredilmemiştir. Bu çalışma kapsamında Revnakoğlu'nun biyografisini aktardığı Bektaşî babalarından İbrahim Baba, Hasan Basri Baba, Tevfik Baba, Ali Fethi Beybaba ve Âlî Bey'e yer verilmiştir. Revnakoğlu notlarından, İstanbul'da bazı tarikatların șeyh ve tekkelerinde Bektașî cihet de tespit edilmiș; Rifâ‘iyye'de Üsküdar Rifâ‘i asitanesinden Ziya Baba ve Kubbeli Tekke'den Molla Bey, Celvetiyye'de Haşim Baba, Halvetiyye'de Ramiz Dede, Mevleviyye'de Abdülvahid Çelebi, Uş̧̧âkiyye'de Yedikule Uşşakî Tekkesi'nden Emin Baba ve halifesi Fahreddin Himmeti Efendi, Nakşibendiyye-i Hâlidiyye'de ise Şeyh Mustafa Efendi bu yönleriyle dikkat çekmiştir. Tasavvufa özel bir ilgisi olan Revnakoğlu hem görevleri hem de bu özel ilgisi dolayısıyla pek çok şeyhle tanışıp tekke ve zaviyelerin çoğunda bulunmuştur. Rumelihisarı Bektaşî Tekkesi şeyhi Nafi' Baba'dan nasip alan babası Server Bey'in de Revnakoğlu'nun sufi çevre ile yakın ilişki kurmasında yardımı olmuştur. Kurduğu bu yakın ilişkiler neticesinde yazılarında kendi gözlemlerini ve etrafındaki kişilerin şahitliklerini aktarmıştır, konuyla ilgili yaptığı değerlendirmeleri ise Türk tarikat tarihinin iç yüzüne ışık tutmaktadır.

Anahtar Kelimeler: Bektaşî babaları, Bektașîleșme, Mevleviyye, Revnakoğlu, Tasavvuf

\section{ABSTRACT}

Cemalettin Server Revnakoğlu, who conducted important research on the history of Istanbul dervish lodges and tariqas, also created a large archive consisting of many documents and items related to the subject. Many documents about Bektashism in his archive are disorganized and not published. The scope of this study includes Baba İbrahim, Baba Hasan Basri, Baba Tevfik, Ali Fethi Beybaba, and Ali BeyBektashi fathers whose biographies have been compiled by Revnakoğlu. His notes also addressed Bektashi aspects in the sheikhs and dervish lodges of Rifa'iyya, Celvetiyya, Khalwatiyya, Mevleviyya, Ussakiyya, and Naqshibandiyya-Khalidiyya tariqas; specifically, he mentioned Baba Ziya, who was the sheikh of Üsküdar Rifa' $i$ Dervish Lodge, and Molla Bey, from Kubbeli Dervish Lodge in Rifa 'iyya; Baba Haşim in Celvetiyya, Dede Ramiz in Khalwatiyya, Abdülvahid Celebi in Mevleviyya, Baba Emin from Yedikule Ussaki Dervish Lodge and his caliph Fahreddin Himmeti Efendi in Ussakiyya, and Sheikh Mustafa Efendi in Naqshibandiyya-Khalidiyya. Revnakoğlu, who had a special interest in Sufism, met many sheikhs and visited most of the dervish lodges and zawiyas due to both his duties and special interest. His father, Mr. Server, who fed off Baba Nafi (sheikh of Rumelihisarı Bektashi Dervish Lodge) also helped Revnakoğlu establish close relations with the Sufi community. As a result, he conveyed his own observations and the testimonies of the people around him in his writings. Keywords: Bektashi Fathers, Bektashization, Mevleviyya, Revnakoğlu, Sufism 


\section{EXTENDED ABSTRACT}

Cemalettin Server Revnakoğlu's personal archive is significant in Turkish cultural history. The archive is currently located in the Süleymaniye Library, and the documents that it contains related to the history of Istanbul Sufism and the tariqas draw special attention. Due to his special interest and duty, Revnakoğlu visited many dervish lodges and zawiyas, shrines and tombs, mosques and kulliyes in Istanbul; he gathered information about these places from both written and oral sources and recorded his own observations.

This study only cites only some of the Bektashi fathers and Bektashi zawiyas from Revnakoğlu's Sufism archive consisting of thousands of documents. Revnakoğlu contacted almost all of the Istanbul Bektashi fathers; he wrote the dervish lodges of Merdivenköy, Çamlıca, Kuyubaşı, Karyağdı, Karaağaç, Sütlüce, Rumelihisarı, and Topkapı Bektaşî and also identified humble Bektaşî lodges operating in Istanbul. He is the only person who has been attributed the titles of sheikh, caliph, professed, and gifted and who wrote about the Istanbul era of the Bektashi-from persons to lodgesfrom the inside. Revnakoğlu, whose father was also a part of Bektashism, personally knew most of the sheikhs that he had spoken with. In the biographies he wrote, what draws attention is his depth, mastery of the subject, and a literary language that is not seen in other studies of this kind. Individuals were determined either directly by their own familiarity or by the testimonies of those around them, and Bektashi fathers were depicted in a style that would make the reader sympathize with them. On the other hand, Revnakoğlu gathered information by asking those who knew the sheikhs what he did not have the chance to know. He included his own observations and evaluations about Baba İbrahim, Baba Hasan Basri, Baba Tevfik, Ali Fethi Beybaba, and Ali Bey, whom we cited in this study, and even recorded rumors about them. Particularly, the wits, rumors and jokes about Baba Tevfik's Bektashism, who was unique to him, have drawn attention. Among other people recalled by Revnakoğlu was Baba Hasan Basri, who had spread Bektashism in the Grand Bazaar and Üsküdar after receiving the diploma for becoming a Bektashi father from Baba Ali Nutku (sheikh of Çamlıca Bektashi Dervish Lodge and Bektashi Ali Bey); although not well known in the field due to his little influence, he has served in many works - especially in the apostils of Aşık Pasha and Lutfî Efendi's Histories. Revnakoğlu also spoke about Ali Fethi Beybaba, who received a diploma from Baba Nutki and was admired by Revnakoğlu because he preserved his childhood embarrassment and never benefited from the tariqa.

It is possible to reach the Bektashi joy-which manifested itself in many tariqas with the decrease in the fanaticism of Bektashism in the nineteenth century - in archive documents. Ziya Efendi (the sheikh of Üsküdar Rifa'i Dervish Lodge) and Baba Emin (the sheikh of Yedikule Ussaki Dervish Lodge) reflected the Bektashi aspects into their tariqas. The latter, a member of a branch that is described as disruptive, transformed 
the Ussakiyya s into the Bektashi color; after him, Caliph Fahreddin Himmeti Efendi carried on the Bektashi joy in Ussakiyya. Baba Haşim, who carried this joy into Celvetiyya, paid the price of his choice because he was Bektashi, and his funeral prayer was not allowed to be performed in the Celvetiyya dervish lodge. When he died, he was brought to the dervish lodge of Celvetiyya to perform the funeral prayer, but he was not taken inside because he was Bektashi, and his funeral prayer was performed near the main door. Later, this place was named the Hashimiyya coffin rest.

Dede Ramiz, of whom Revnakoğlu claimed to know every aspect and sometimes criticized for his behavior, brought Bektashi joy to Khalwatiyya. On the other hand, Sheikh Mustafa Efendi, who was said to be an astonishingly Alevi with his long mustache, brought the Bektashi joy into Naqshibandiyya. Some of the sheikhs, whom Revnakoğlu stated belonged to other tariqas while tending toward Bektashi, had benefited from both being Bektashi and the status of fatherhood. One of these sheikhs was Abdülvahid Çelebi from Mevleviyya, who reflected the Bektashi color most intensely in Mevleviyya; moreover, the sheikh of Bahariye Mevlevi Lodge, Dede Hüseyin Fahreddin, also fed off the sheikh of Sütlüce Bektashi Dervish Lodge, Baba Münir. Revnakoğlu conveyed the biography of Abdülvahid Çelebi, who received his caliphate from Bektashiyya and made his contribution, with his remarkable aspects. Revnakoğlu related that Abdülvahid Çelebi was not liked by the palace and some Bektashi people because he helped the libertarians, and he also touched on the jealousy in Bektashiyya. A copy of a long document in which Abdülvahid Çelebi confessed to being Bektashi is preserved in the Revnakoğlu archive. This document reflects many folkloric materials, beliefs, and practices regarding daily life and special days such as Muharram. All these documents in Revnakoğlu's archive, who also gathered information about Bektashism while working on the history of Istanbul dervish lodges, prevented the forgetting and progressive loss of information belonging to the last period of this history. 


\section{GíRiş}

İstanbul'un sufî müesseselerinin kapanış devrini içeriden, bizzat tanıklık ederek yazmış olan Revnakoğlu'nun (1912-1968) çoğu el yazısı hâlinde kalmış, neşir yüzü görmemiş notlarında tekkelerin iç tarihi hayli yekûn tutar. O, İstanbul Bektaşî babalarının hemen tamamıyla temas kurmuş; Merdivenköy, Çamlıca, Kuyubaşı, Karyağdı, Karaağaç, Sütlüce, Rumelihisarı ve Topkapı Bektaşî tekkelerini yazmış, ayrıca İstanbul'da faaliyet gösteren mütevazı Bektaşî zaviyelerini de tespit etmişti. O, doğrudan şeyh, halife, ikrarlı ve nasipli sıfatlarını haiz Bektaşîlerin İstanbul devrini şahıs şahıs, tekke tekke içeriden yazan yegâne kalemdir. Kendisi Bektaşî olmadığı hâlde birçok babanın hizmetinde bulunmuş, 1968'de vefatına kadar temas kurduğu birçok Bektaşî babasının biyografilerini kaleme almıştı. Bektaşîliğe alâkalı vesikalar, onun arşivinin mühim cephesini teşkil eder. Revnakoğlu'nun babası Server Bey'in nasibi Rumelihisarı Bektaşî Tekkesi şeyhi Nâfi' Baba'dan, babalık unvanı da oğlu Mahmud Baba'dandı.

Revnakoğlu, Bektaşîliği ve Bektaşîlik karşısında kendi vaziyetini 22 Ekim 1952 tarihli Vakit'te "Bektaşîlikte Dinî Bir Ayin Var mı?” başlığıyla çıkan yazısında hülâsa eder:

Kendim Bektaşî değilim, fakat Bektaşîleri çok severim, onlara karşı yakınlığım eskidir. Bu can adamların içinde tahsil, terbiye görmüş, meydan ve erkân açmış, cem yürütmüş İstanbul efendisi inceliğinde zarafet ve irfan sahibi kıdemli babalardan hayli dostlarım ve aşinalarım vardır.

Meclislerinde, hususî âlemlerinde bir defa bulunmuş olanlar bilirler ki her hâli ile samimî, dost doğru insanlardır, kadirbilirlikleri, vefakârlıkları en başta gelir, sevdikleri, sevmedikleri herkese aynı muameleyi ederler, olduğu gibi görünürler, göründükleri gibi de olmaya çalışırlar. İnsanları sınıflamazlar, kim olursa olsun herkesi bir tutarlar. Her şeyde içinin ilhamı, ruhunun sesi ile konuşurlar, sözden ziyade öze bakarlar, şekil ve suretten daha çok ruha, hakikate kıymet verirler, her şeyi hoş gördükleri hâlde iki din kullanan maskeli yüzden hoşlanmazlar, fitne ve nifakçılıktan iğrenirler.

Umur görmüş eskilerinin çoğu da Mevlevî arifleri gibi gerçekten irfan sahibi, olgun, hâl ehli, nükteye mail ve deryadil kimselerdir; muhabbet ve sohbetlerine doyum olmaz, gönül çalarlar, meclis doldururlar. Aralarındaki birlik ve bağlılığın sarsılmaz kudretini başka tarikat mensuplarında göremezsiniz. İkrar bendeliğinin üstünde başka bir saltanat bilmezler. Erenler meydanında edebin sembolü olarak eline, diline, beline sımsıkı insanlardır. Ağızlarını dudaklarına kadar örten bıyıkları onlardan sır çıkmayacağını, ağızlarının daima mühürlü olduğunu bildirir. Kesreti vahdete giydirip görünüşte koca bir cemiyet hâlinde, fakat manada ve hakikatte tek vücut olarak yaşarlar.

Bu Horasan erleri içinde mesel olmuş şekli ile "Ser verip sır vermeyen"ler pek çoktur, bu hususta son derece muhafazakâr, gayet dikkatli ve titizdirler. Bu sebepledir ki "marifet" denilen ilâhî irfandan ve zevkten nasibi olmayan ham ervah cinsine dil 
olmak istemezler, herkesi her hakikatten agâh etmenin esasen mümkün olmayacağını bilirler. Ve yine bilirler ki irşat etmek, uyandırmak, uyanmaya niyyet ve istidadı olanlar içindir; gözü açık körlere, körü körüne inat edenlere bir şey yapılmaz...

Başka tarikatlarda görüldüğü gibi Arap, Acem hars ve edebiyatının tesirleri altında kalmamıştır; halkın içinden, özünden doğmuştur. Halktan ayrılan bir tarafı olmadığ için her şeyi sade ve külfetsizdir. "Terceman" denilen manzum duaların metninden melodisine, tavrına, üslûbuna kadar her şeyi Türk olan biricik tarikattır. Bir başka niyaz manzumesi olarak çekilen gülbanklar, ilâhîler, tevriyeli tabirler, sstılahlar (terim) hülasa söylenilen ve konuşulan ne varsa hepsi Türkçedir. Hatta on iki imama işaret maksadı ile on iki kıta yazılan, her parçası "Hamse-i Âl-i Abâ"yı telmih için beş mısra tutan nefeslerin nazım şekli, pürüzsüz dili ve duygusu hep Türkçe olduğu gibi, vezni ve imlâsı da yine Türkçedir.

Kaleme aldığı biyografilerde bu tür diğer çalışmalarda görülmeyen bir derinlik, mevzuya hâkimiyet ve edebî bir dil göze çarpar. Şahıslar ya doğrudan kendi aşinalığıyla ya da etraflarındakilerin şahitlikleriyle yakından tespit edilmiş, okuyucuya hissettirilecek bir üslupla Bektaşî babaları işlenmiştir. İstanbul Bektaşîlerinin hemen bütün kadrosu onun 377 dosya tutan terekesine yayılır. Hazırladığımız Revnakoğlu kitabına aktardığımız kadrodan hariçte kalan İbrahim Baba, Hasan Basri Baba, Tevfik Baba, Ali Fethi Beybaba ve Âlî Bey (Topal Ali Bey) biyografileri Revnakoğlu'nun dosyalarından alınmıştır. Alıntılarda iki noktadan önceki rakamlar, Süleymaniye Kütüphanesi'ndeki Revnakoğlu dosya numaraları; iki noktadan sonraki rakamlarsa dosyaların imaj numaralarıdır.

\section{Bektaşî Babalar}

İbrahim Baba (Hacı, Tatar İbrahim Baba, Küçük İbrahim Baba, Köşklü İbrahim, Sandalcı İbrahim, Bursalı İbrahim Baba) (304:-2133): Mücerret babalardandır. Filibelidir, Filibe'nin Komanovalı soyundan Mehmed Efendi'nin oğlu idi. Eski aile adı "Komanovalığlu"dur. H.1266 tarihinde Filibe'de doğmuştu. Sütlüce Bektaşî Tekkesi şeyhi Münir Baba'nın eski muhiblerindendir. Daha önce Kâdiriyye tarikinde bulunmuştu. Bektaşîliğini Münir Baba'nın yanında tamamlamış ve ona yıllarca pervane olmuş ve üçüncü rehber olarak yine Münir Baba meydanında hizmete soyunmuştur. Münir Baba'nın kıdemli baş rehberi Şair İbrahim Mihrâbî Baba'dan ayırmak için İbrahim Fevzi Baba'ya "Küçük İbrahim Baba", ayrıca "Tatar İbrahim Baba" derler. Gençliğinde Beyazıt yangın kulesinde köşklü olarak İstanbul sokaklarını dolaştığından "Köşklü İbrahim" de demişlerdir. Bir ara Haliç'te sandalcılık ettiğini bilenler "Sandalcı İbrahim" derlerdi. Hayatının son uzun yıllarını Bursa'da geçirmiş olması, kendisine "Bursalı İbrahim Baba" dedirtmeye sebep olmuştu.

Nasibi, dervişliği Münir Baba'dan, babalık icazeti pîr evi postnişini Hacı Feyzullah Dedebaba'dandır. Pîr makamında on iki yıl süren hizmet derecelerini bitirdikten sonra $\mathrm{H}$. 1315 tarihinde kendisine babalık verilmiştir. 
Gönülsüz, gösterişsiz bir adamdı. "Baba" unvanını aldıktan sonra bile eskilerin usulünü bırakmayarak isminin üzerine "baba" yerine "türbedar", "zaviyedar" yahut "Derviş İbrahim b. Mehmed" gibi eklemeler yapmakla yetinirdi. Cehlini, kifayetsizliğini bilecek kadar insafi vardı. Hiç tahsili olmamakla beraber görgüsü vardı, hizmetten yetişmişti. "Şeyhlik de babalık da aslında dervişlikten ibarettir, derviş olabilmektir. Şeyhliğin üstün sayılacak bir tarafı yoktur, maksat adam olmak, insan olmak, insanlığa faydalı bir iş yapabilmek, kendisini hayırla yâd ettirebilmektir. Başımızda külâh ne cinsten olursa olsun yolunda bulunduğumuz makamın pîrini temsil etmekten ibarettir. İnsan değilsek, insan olmanın yolunda bulunmuyorsak o bize 1şık tutmaz ve bizi adam etmez!" der dururdu. Dediklerini sözde bırakmaz, bizzat yapardı, bundan dolayı hiçbir işini kimseye gördürmez, odasını süpürür, çamaşırını kendi yıkar, dikişlerini kendi diker, yemeğini kendisi pişirirdi.

Süsten, gösterişten hoşlanmadığı için daima köylü kıyafetinde gezerdi. Başında kaba dikişli, perişan destarlı, kalıpsız bir taç taşır, kaşlarının üstüne indirdiği bu tacın rengi ağarmayınca destarını değiştirmeyi düşünmezdi. Sırtındaki hırkası, kemeri, ayağındaki kalın yün çoraplar gibi tacını, takkesini de kendi dikerdi, fakat süslemek, işlemek için hiç önemsemezdi, her yerini kaba dikişlerle teyellerdi. Başkaları için kendisine 1smarlanan taçları ise bunun tam aksine fevkalâde güzel işlerdi, Kâdirî, Rifâ‘î, Bedevî güllerini işlemekte ustalığı vardı. Değerli bir sanat eseri hâlinde günlerce emek vererek vücuda getirdiği bu çeşit güller ve tâc-1 şerîfler için ne kadar zorlasalar karşılığında hiçbir şey kabul etmezdi.

Her hareketi ile derviş olduğunu gösterirdi. "Tasavvuf yâr olup bâr olmamaktır" denildiği gibi o da asıl dervişlik başkasının sırtına yüklemek değil, kendi sırtında taşımaktır demek isterdi.

Çok memleket görmüştü, dolaşmadığ 1 yer kalmamıştı, Bağdat'tan Samarra'ya, oradan Kerbelâ'ya kadar selmân ederek yaya gitmişti. Gezdiği, kaldığı birçok yerlerde nasip vererek canlar uyandırdı. Bu yüzden kendisine "Hacı Baba", "Seyyar Baba" denilirdi.

Merdivenköy Tekkesi'ne İttihat ve Terakki'nin umumî merkezi tarafından getirilmişti. Sütlüce Bektaşî Tekkesi şeyhi Münir Baba'nın oğlu merhum Hüseyin Avni Bey o tarihlerde İttihat ve Terakki Fırkası'nın mesul kâtip muavini bulunuyordu, onun nüfuz ve aracılığı ile Merdivenköy Tekkesi şeyhliğini İbrahim Baba'ya verdiler. Mütarekeye kadar burada bulundu, sonra İtilâfçılar gelince tekkede kalamayacağını anladı, Merdivenköy'den ayrılıp Bursa'ya geldi.

Vefatına kadar uzun yıllar kaldığı, barındığı Bursa'da geçinmek için çeşitli işler yaptı, Kediler Tekkesi Camii'nin imamlığını yaptı, fakat rahatsızlığı dolayısıyla bunu devam ettiremedi. Nihayet Bursa Müzesi'ne kapıcı oldu. Aldığı para yetmiyordu. Yalnızlık, bakımsızlık yüzünden çok sık hastalanıyordu. Son yılları hazin bir perişanlık içinde geçti. Bir akşam müze dönüşünde Dereköprüsü üstünden geçerken düşüp ayağı kırıldı. Durumu büsbütün fenalaştı. Bursa'da Pullukçu İsmail Pişkin isimli iyilik sever bir zat, babayı ahırına aldı, üç ay kadar ona baktı, ne lâzımsa yaptı. Fakat babanın sağlık durumu ağırlaşınca onu guraba hastanesine (şimdiki devlet hastanesine) yatırdılar. Ameliyat edilmesi lâzım geliyordu. "Huzûr-1 kibriyâya sakat, noksan aza ile çıkamam!" diye razı olmadı. Kısa bir süre sonra cemal âlemine göç etti: 1935. 
Zindankapısı çevresinde Alaca Hırka'da Garipler Mezarlığı'nda yatıyor. Taş konulmadığgndan yerini bulmak kabil değildir. Kendisinden sonra Merdivenköy'e Topal Tevfik Baba geldi, resmî türbedar olarak da Kazasker İsmet Molla gönderildi

Hacı İbrahim babadan nasip alanlar (Beylerbeyli merhum Hüsameddin Bey'in ve Necmi Baba'nın söylediklerine göre): Nazif Efendi: Bursa'da oyuncakçı idi. Oğlu, babasının dükkânında şimdi yine oyuncakçıdır. Osman Efendi: Bursa'da kavaf idi. Bursa Kediler Tekkesi son şeyhinden önceki postnişin efendi...

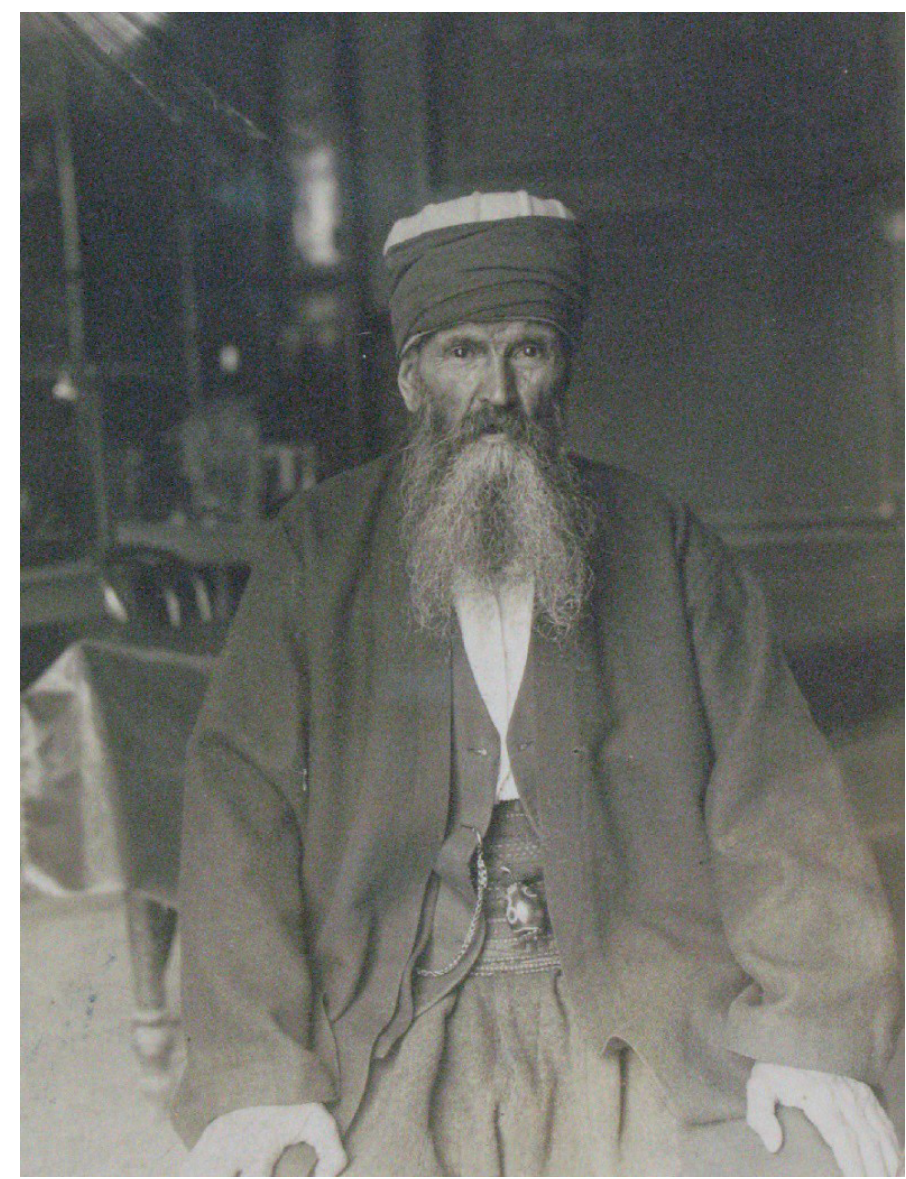

İbrahim Baba 


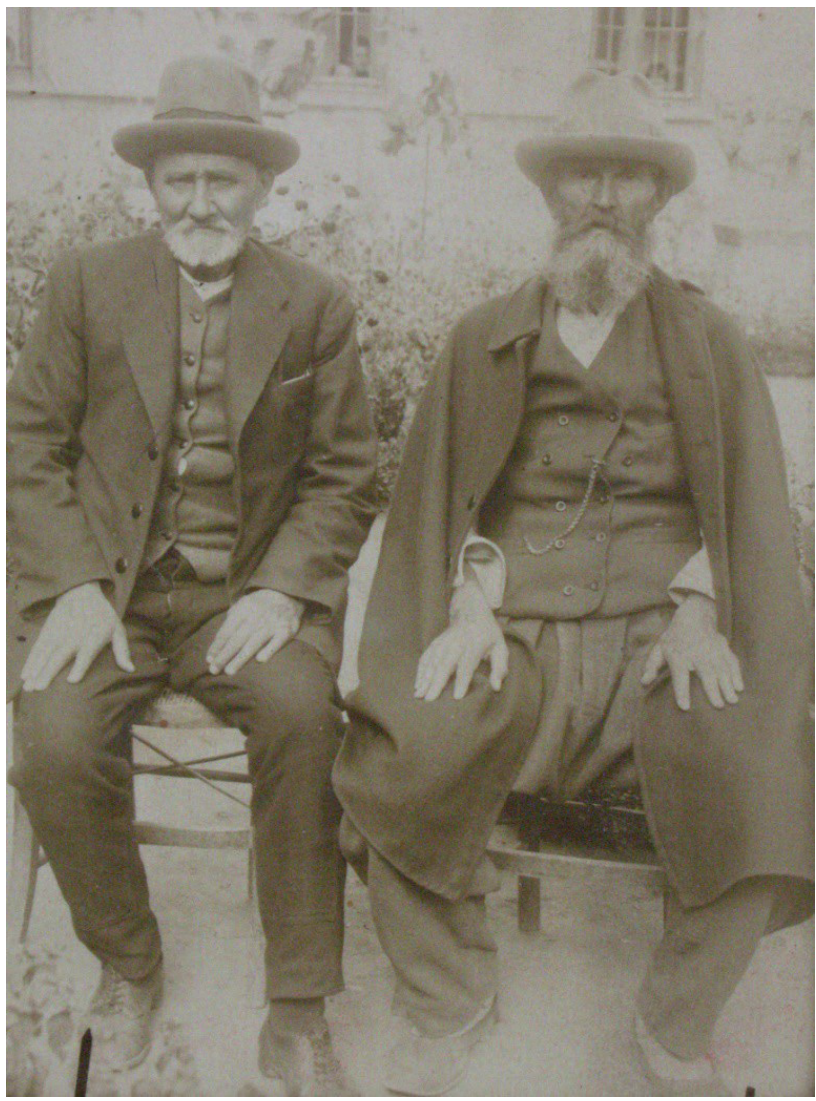

İbrahim Baba (sağdaki)

Hasan Basri Baba (Tapduk) (254:310-320): Kapalıçarşı'da kadın elbisecisi idi, "Esvapçı", "Zenneci", "Yağlıç̧ı" derlerdi. H.1290 tarihinde Üsküdar'da Hazret-i Hüdayi Sokağı'nda 10 numaralı baba evinde dünyaya gelmişti. Üsküdar Harem İskelesi mütevellisi Habîb Ağa'nın oğlu idi; onun da babası yine Üsküdarlı Ali Ağa'dır.

Hasan Basri Baba aslında Kâdirî dervişidir. Nuruosmaniye'de Mengene Sokağı'nda Kâdiriyye'den Yusuf Baba Tekkesi'nin postnişini Yusuf Hakkı Babazâde Münzevi Ali Efendi'ye intisap etmişti. Bu tekkede uzun zaman kaldı. Tarikatın mutat hizmetlerini ve seyr ü sülûkunu bitirdikten sonra 23 yaşında iken Münzevî Alî Baba'dan istihlâf olundu: 1310. Bektaşiyye'den ilk nasibi Nevrekoplu Hüsnü Baba'dandır, sonra Çamlıca Bektaşî Tekkesi postnişini Ali Nutkî Baba'dan babalık icazetnamesi aldı. Duyup dinleme suretiyle bellediği ve onlarca bilgiden sayılan bazı şeylerle bilhassa manzum söz söylemekteki kabiliyyeti ile etrafını uyandırmağa çalıştı. Kapalıçarşı ve Üsküdar çevresindeki bazı kimselere Bektaşiîliğgi ve Bektaşî akidesini aşılamağa muvaffak oldu, bunların bir kısmı münevver insanlardı. 
Basri Baba nazik, terbiyeli, güleryüzlü, pek kalender ve sevimli bir zat olduğundan kendisiyle görüşen, sohbetinde bulunan mutlaka onu sever, dediğinden ve yolundan ayrılmak istemezdi; şahsî sempatisi dolayısıyla etrafına toplananlar gittikçe fazlalaşırdı; son devrin ilim ve irfan sahibi, en eski Halvetî şeyhi ve Bektaşî Babası Salih Râmiz Baba bunlardan biridir. Hasan Basri Baba son derece sehi idi, evine gelene mutlaka lokma çıkarır (sofra kurar), bizzat hizmetinde bulunurdu. Kendisi içtiği için sofrasında içki de bulundururdu, fakat içilip içilmemesini herkesin arzusuna bırakırdı, katiyen ısrar etmezdi hatta "Bu kusuru işliyoruz, Allah affetsin!" derdi. Yardıma muhtaç olanlarla ilgilenmek, onlara yapılması lazım gelen maddî, manevî her türlü yardımda bulunmak, onların işlerine bakmak Basri Baba'nın dükkândaki işleri ve çalışmaları arasında ayrı bir yer tutardı. Misafirliğe gittiği veya ziyaretinde bulunduğu bir dostunun evine eli boş gitmezdi; etrafındakilere de sırası geldiği zaman "Hiçbir şey getiremeyen veya bulamayan hiç değilse bir yeşil yaprak ile gelmeli, bir çiçek ile olsun gönül almalı, bu muhabbetin ifadesidir" derdi.Üsküdar'da Gümüş Arayıcı'daki evinde kısa süren bir rahatsızlıktan sonra 24 Ocak 1938 pazartesi günü vefat ettiği zaman yaşı 76'ya yetmişti. Karacaahmet'te Şehitlik'te gasilhanenin haremlik tarafında caddeden yüz metre kadar içeride yatıyor, taşı yoktur...

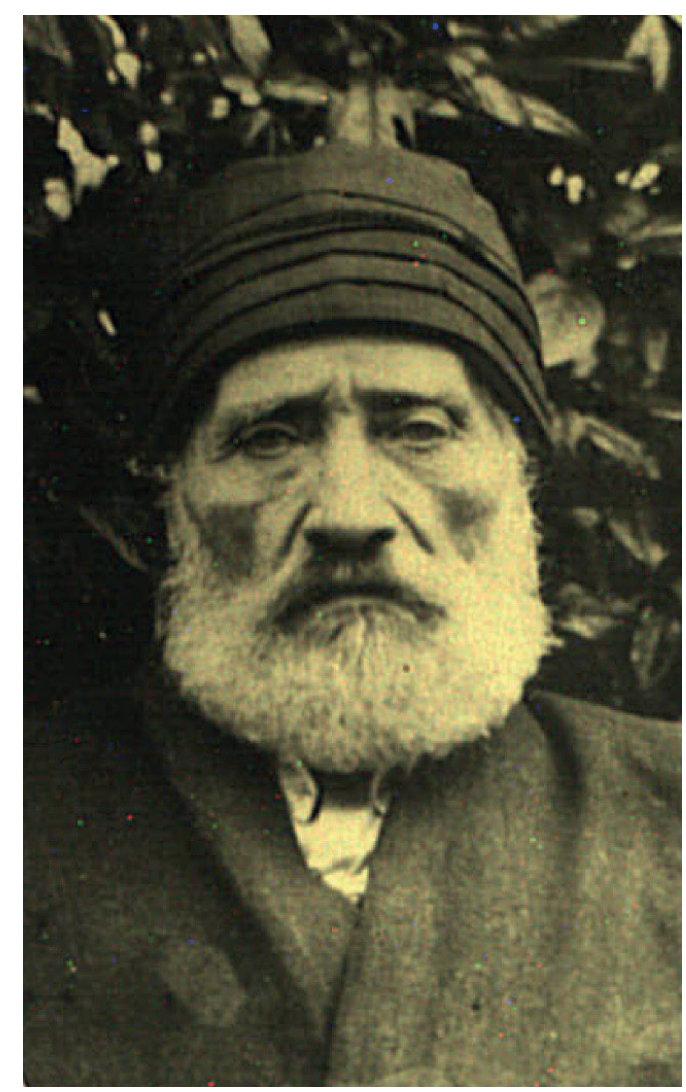

Hasan Basri Baba (Tapduk) 
Üsküdarlı Hasan Basri Baba aslında Kâdiriyye ve Uşşâkiyye meşayihindendir, Bektaşîliği sonradandır ve ilk nasibi Nevrekoplu Hüsnü Baba'dandır. Postacı Ali Baba'dan icazetli bulunan Üsküplü Marangoz Yusuf Ziyâeddîn Baba'nın da ilk nasibi Hasan Basri Baba'dandır. Herkesi nazarında bir gören kâmil insandı, sehi idi. Edremitli Kâdiriyye meşayihinden şair Haydar Efendi, Hasan Basri Baba'dan nasip almıştı, Kâdirîliği de ondan ikmal eylemiştir. Sinâniyye meşayihinden Üsküplü Şeyh Râmiz Efendi de Basri Baba'nın hizmetinde bulunmuş, ona biat etmiş ve ondan taç giymiştir, en sonra da Postacı Alî Baba'dan teberrüken icazet almıştı.

Basri Baba'dan nasip alanlar: Saim Sarıgül (şimdi senatördür), Ziya Baba (Üsküplü, marangoz), Şükrü Can (Üsküplüdür, göçtü), Osman Metin (Selanik dönmelerinden), Nusret Tınay (Laleli'de züccaciyeci), Nuri (Darbhanede memur). Basri Baba, Nusret Tinay'a nasip verdiği gece Müftü Baba'ya da babalık icazetnamesi verdi. Nusret Tınay, Basri Baba'nın en son muhibbidir.

Tevfik Baba (Topal, Yalvaçlı Mehmed Tevfik Baba) (286:15-31): “Toplu Tevfik Baba" da derlerdi. Medrese tahsili görmüştür, hocalıktan gelmedir. Evvelce Kâdirî tarikatına bağlı iken sonra Bektaşiliğge girdi. Nasibi ve dervişliği Dedebaba'dandır [Mehmed Ali Hilmi Dedebaba] Rumelihisarı'nda Şehitlik Tekkesi postnişini meşhur Nâfi' Baba'dan babalık icazesi ve pîr evi postnişini Hacı Feyzullah Dedebaba'dan da hilâfet icazetnamesi aldı. 1339 tarihinde İbrahim Fevzi Baba'nn çekilmesi üzerine Şahkulu Sultan Dergâhı'na halife rütbesi ile baba olmuştu. $\mathrm{Bu}$ dergâhın son resmî babalığ̣ kendisiyle sona erdi. Merdivenköy Tekkesi'ne yerleşmeden önce Topkapı Bektaşî Tekkesi'nde oturuyordu.

Bektaşîliğe girişinin ilk zamanlarında Merdivenköy Dergâhı'nda kahve nakipliği etmiş, Dedebaba'dan dervişlik tacı giymiş ve yine ondan mücerret erkânı görmüş ve pîr evinin son postnişini Salih Niyazi Baba'dan da ayrıca hilâfet erkânı görerek halifebaba olmuştu.

İstanbul'da resmî olarak en son ve en uzun halifebabalık eden Kırşehir'deki pîr evi makamını ve babalığını resmî şekilde İstanbul'da temsil eden Tevfik Baba olmuştu.

Sultan Mahmud zamanındaki Bektaşî kıtalinden sonra İstanbul'da bütün Bektaşî tekkeleri ister istemez Nakşibendiyye'den gösterilmesi zarureti vardı. İtilâfçıların adamı olarak Merdivenköy Dergâh'ı şeyhliğine getirilen Tevfik Baba'nın da bu sebeple Meclis-i Meşâyih'e resmen bir Nakşibendiyye icazetnamesi sunması gerekiyordu. Bunun da çaresini bulup zamanın rintmeşrep zarif ve deryadil şeyhlerinden, birçok tarikatlardan teberrüken izinli ve şöhretli, aynı zamanda birinci sınıf dua üstatlarından Üsküdarlı Balabanî Şeyh Hüseyin Hüsnü Efendi'den kendisine usulen bir Nakşibendiyye icazetnamesi yazdırdı.

Yarı ciddi yarı latife yoluyla gelen söylentilere göre bu teberrük icazetnamesi Balabanî merhuma Üsküdar'da bir attar dükkânında dört mecidiye vermek suretiyle hazırlanmıştır. Hatta yine söylerler, zamanın Meclis-i Meşâyih reisi ve Hazret-i Hüdâî Hankahı şeyhi Gülşen Efendi bunu duyunca kızmış, üzülmüş, Balabanî'ye huzuruna çağırtıp sormuş: 
-Şeyh efendi, yakışır mı bu hâl? Neden böyle yapıyorsun? Zarafette, hazırcevaplıkta bir tane olan Balabanî hemen yetiştirmiş:

-Efendi hazretleri demiş, insaf buyurun, şu aldığım paranın hepsi topu topu dört mecidiye. İkisi icazetin yazılmasına verildi, ikisini de mühür parası diye aldım. Bu dört mecidilik icazetnameyi benden değil de gidip Bâyezîd-i Bistâmî'den mi alacaktı?

Gülüşmüşler, bir şey diyememişler.

Hürriyet ve İtilâf Fırkası'nın iktidar mevkiine geldiği sıralarda Merdivenköy Dergâhı'na kayd-1 hayât şartıyla postnişin olan ve sonra "Tarîkat-1 Salâhiyye"ye intisabı dolayısıyla istiklâl mahkemesine verilen Tevfik Baba daha sonra istiklâl harbi başlarında yararlı işler gördüğü tesbit edilerek kendisine istiklâl madalyası verilmişti.

Şeriatta ve imamet bahsinde sakat olanların mihraba geçip namaz kıldırması caiz olmadığı gibi, Bektaşîlikte de sakat veya vücudunda arızası olanlara babalık makamı veya rütbesi aslâ verilmez. Hâl böyle iken topallığı ile tanınmış ve ismine de eklenmiş olan Yalvaçlı Tevfik Efendi'nin icazetname alması geleneğe bağlı eski muhipler arasında haklı bir hayret ve garabet uyandırmıştı. Bunların çoğu Tevfik Baba'nın doğuşta aksak olmayıp bir arıza neticesinde sonradan topallaştığını öğrenmişlerdi.

Babalığı hakkında ağızlarda dolaşan bir rivayet de şöyledir: Güya Köse Nuri Baba ile kendisi, Dedebaba'nın hastalığı sırasında icazetnameyi yazıp hazırlamışlar, baba göçünce hemen mührünü alıp icazetnameye basmışlar derler. Yine onun hakkında dinlediğimiz dedikodulardan biri de şudur: Bektaşî teamülüne göre mücerret ikrarı verenlerin mutlaka Kırşehir'e pîr makamına gitmesi ve orada erkân sahibi Balım Sultan'ın türbesinin eşiğinde şimşir kaşık ile sağ kulağını deldirmesi şarttır, öteden beri yapılan, yaptırılan çok eski usul budur. Tevfik Baba buna aykırı olarak Merdivenköy'de kulak deldirmeye başlamış, bizzat kendi de mücerretlik alâmeti olan mengûş isimli küpe halkayı kulağına bu tekkede geçirmiştir. Gelenekleri ile yaşayan koyu Bektaşîler, Tevfik Baba'nın bu hareketini yanlış ve usulsüz bir bidat olarak karşılamışlardı. Yine onun Sirkeci'de Hamidiye Hanı'nda avukatlık eden bir Ermeni hukukçuya nasip vermiş olmasını da uygun görmemişlerdi.

Biraz karışık geçmiş olan siyaset tarafına gelince: Tevfik Baba, "İslâm masonları" denilen "Tarîkat-1 Salâhiyye"nin kırklarına dahildi. Başlarında bulunan Sultan Vahidüddin gavs-1 a 'zam bilinirdi. Birinci sınıf üyeleri Sultan Vahidüddin'in baş yaveri Bektaşiyye'den Kiraz Hamdi Paşa, eski masonlardan İsa Ruhî Paşa ile müverrih Ahmed Refik Bey'den meydana geliyordu ve bunlara "Üçler" denilmişti. Tevfik Baba, Merdivenköy'e postnişin olunca bu mesele ortaya çıktı ve millî hükûmet Anadolu'da kuvvet bulunca Tevfik Baba'nın durumu istiklâl mahkemesince ele alındı. Tarîkat-ı Salâhiyye'nin içinde görünen ve güya Hürriyet ve İtilâf Fırkası namına çalıştığı sanılan Tevfik Baba, karşı tarafa bilgi veriyor, millî hükûmeti tutuyor ve her yaptığını gerçekte onlar adına yapıyor ve iki tarafı da sezdirmeden idare ediyordu. Hizmet ve başarıları ilgili makamlarca bilindiği için istiklâl madalyası bundan dolayı verilmişti. 
Netice itibarıyla Tevfik Baba aslında ilmiyeden gelen bir zat olduğu için eli kalem tutan mürekkep yalamış, yerine göre konuşmasını bilir, sözü sohbeti dinlenilir, muhabbetlerde özlenir ve aranılırd1. Ubeydullah Efendi ile İsmet Molla'dan başka Merdivenköy'de postnişin olanlar içinde en münevver insand. Sohbetleri ilmî ve kitabî olurdu, dinleyenler mutlaka faydalanırlardı. Çağdaşı ve arkadaşı bulunan diğer babalardan birçoğunu her münasip vesile ile bazı gerçekler ve incelikler üzerine irşada çalışırdı, onlar da bu yüzden kendisine büyük saygı gösterirlerdi. Babalıkta kıdemli olanlar bile ilmî müşkillerini çözmek için ona niyaza gelirlerdi. Tekkelerin seddinden sonra Merdivenköy'den ayrılmamıştı. 1930 yılında Üsküdar Numune Hastanesi'nde tedavi edilmekte iken göçtü. Hastaneye yatırıldığı zaman sakalını kestikleri için ağlamıştı. Merdivenköy Tekkesi haziresinde yatıyor, taşı ve mezarı hâlâ yaptırılmamıştır.

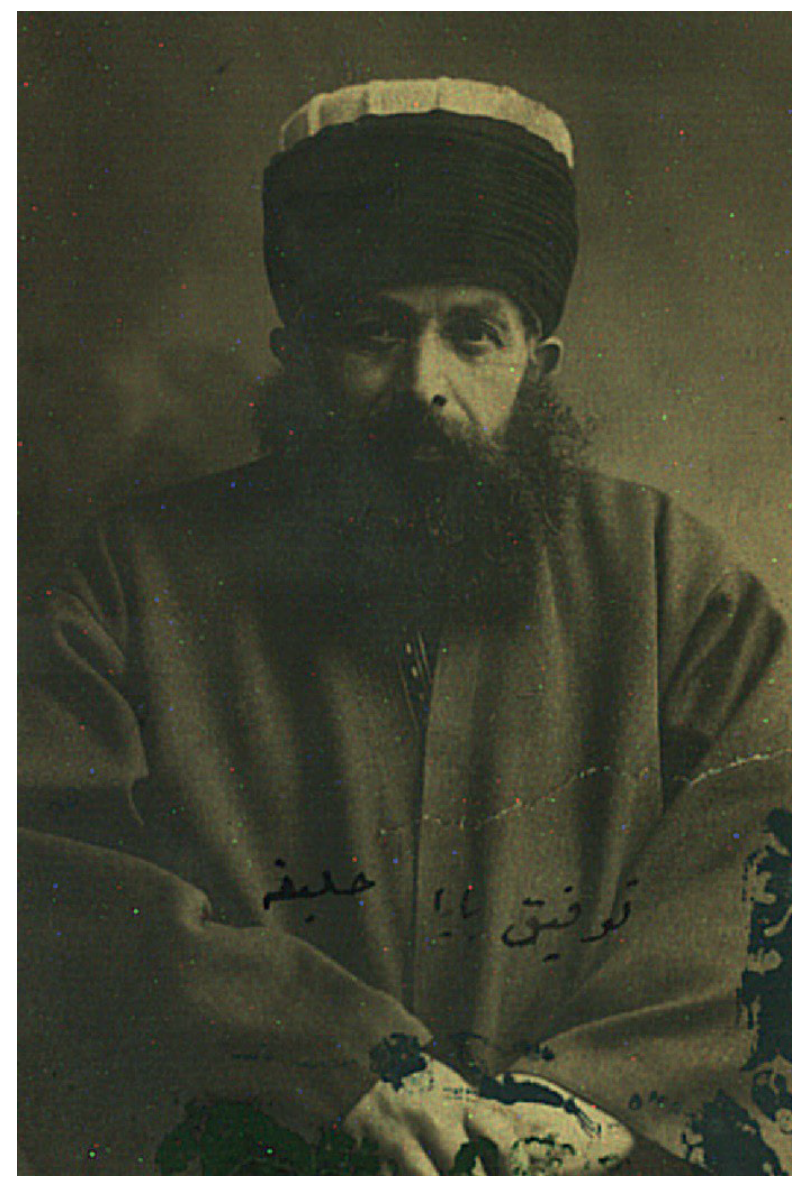

Tevfik Baba 
Ali Fethi Beybaba (254:105-109): Nasibi Hüseyin Zeki Baba'dandır. Nutkî Baba'dan icazet aldığı zaman rehberliğini Postacı Ali Cemalî Baba yapmıştı. Piyade binbaşılığından emekliye çıktıktan sonra vefatına kadar Kadıköy'de Moda'da oturdu. Kendisini tamamıyla okumaya vermişti; mütalaası, mahfuzatı başkalarının istifade edebileceği kadar zengindi. Terbiye ve nezaket örneği gösterilecek çok kibar insandı. Saçı başı ak pak olduğu hâlde çocukluk safvet ve mahcubiyetini hâlâ kaybetmemişti. Bütün hayatında daima çekingen ve mütereddit yaşadı. Tarikat hurafelerinden ve çıkar sağlamak için uydurulmuş taraflarından ziyade esas ve gerçeğe kıymet verirdi, bundan dolayı kimseden niyaz kabul etmedi. Usulden olarak niyaz bırakmağa alışmış olanlara: "İhtiyacı olanlara götürün, daha iyi edersiniz!" derdi, getirilen nezir ne miktarda olursa olsun elini asla sürmezdi ve bütün terbiyesine, inceliğine rağmen nezir getirmekte yine ısrar edenleri azarlamak zorunda kalırdı. Bu işi eskiden beri sürüp gelen bir usul, bir anane şeklinde değil de tamamıyla bir geçim vasıtası hâline getirenler ibretle öğrensinler!

Ali Fethi Baba her hâliyle hakikaten pek nazik, terbiyeli bir zattı, Bektaşîliğin zarafet ve muaşeretini son zamanlarda temsil edenlerden aramızda nümune olarak yaşıyordu, bu yüzden çelebi hâlleri ve efendiliği ile herkesi kendisine meclûp etmişti. Kurban bayramı arefesine rastlayan 29 Temmuz 1955 tarihinde kendisini Hakk'a kurban eyledi, tam 78 yaşında bulunuyordu...

Âlî Bey (Topal Âlî Bey) (248:51): “Topal Âlî Bey” derlerdi. Topkapı Sarayı Âsâr-1 Atîka Müzesi memurlarından idi. Eski muhiplerden bulunduğu için İstanbul Bektaşîleri arasında çok sayg1 görürdü. Rumelihisarı Bektaşî Tekkesi postnişini Mahmud Baba'nın Maârif Târîhçe-i Teşkîlâtı da onun tarafından tamamlanmıştır. İrfanlı, faziletli bir zat idi. Sahasında pek sessiz çalışan bir kimse olduğu için Âşık Paşa ve Lutfî Efendi tarihlerinin bütün haşiyelerini kendisi yazdığı hâlde pek bilinmemiş, duyulmamıştı. Tarih Encümeni dergilerinin ve Halil Edhem Bey'in eserlerinden çoğunun fihristlerini de kendi kaleminden çıkarmıştı.

\section{Revnakoğlu Notlarında İstanbul Tekkelerinde Bektaşileşme}

\section{Rifâ'iyye'den:}

Bu tarikatta Bektaşîlik cihetiyle en maruf şahsiyet, Üsküdar Rifâ‘î Asitanesi şeyhi Ziya Efendi/Ziya Baba'ydı. Tam adı Abdülkadir Ahmed Ziyaeddin Salâhî olan Ziya Efendi, ilmiyeden olduğu için kendisine "Ziya Molla" da denilirdi. Büyük Tevfik Efendi'nin oğlu ve halifesiydi. Şeyhin başında Bektaşî fahriyle sokaklarda dolaşması Sadeddin Nüzhet Ergun'un şiddetle tenkit ettiği bir vaziyetti (Ergun, II, 1943: 410). Hüseyin Vassaf da bu şeyhi sevmiyor, onun için hezeyan yolunu tutmuş, tarikata hurafeler katmış, diyordu. Hatta dilini tutamamış, Ziya Efendi için "Tîg-1 ecel bir an evvel harbe-i kahrına alarak vücûdunu ortadan kaldırmıştır!" demişti. (Vassaf, I, 2006: 261-262) 17 Aralık 1917'de vefat eden Ziya Efendi'ye dair biyografik malzeme Revnakoğlu'nda şu şekilde kayıtlıdır (168:25-49): 
Tasavvufa olduğu kadar fikıh ve tefsire de vâkıf olduğundan Üsküdar Yeni Câmi‘-i şerîfinde ve Davut Paşa'da ve Hazret-i Hüdâî Hankahı'nda yaptığı vaaz ve nasihatlerinden kadın, erkek, bilhassa gençler, münevverler her suretle istifade ederlerdi. Zaten gayetle beşûs, mültefit, güzel yüzlü, güzel sözlü, arif, nüktedan, fevkalâde kibar ve rintmeşrep bir zat olduğundan herkes tarafından fazlasıyla sevilir ve hürmet görürdü. Malı mülkü olmadığı hâlde sehâsı ve zekâsı birbiriyle yarış eder hâldeydi. Hırkasını sırtından çıkarıp fukaraya verecek kadar mükerrem ve feragatkâr olduğunu söylerler. Son derece temiz giyinirdi. Uyanık, teceddütperver bir insan olduğundan, biraz da içtihat neşesinin galebesiyle kendi dervişlerinin arakiyeleri üzerine Edhemî terkler şeklinde siyah şerit ve kaytanlar diktirmişti ki sonradan bu usulü Beylerbeyi Settâriyye şeyhi Râmî Bey de kendince muvafik bularak mensuplarına bu tarzda kırmızı şerit taktırmış olduğu görülür.

Ziya Molla'nın Üsküdar'daki Malatyalı İsmail Ağa Câmi‘-i şerîfinde imamlığı da vardı. Sa'diyye'den Malatyalı İsmail Ağa Tekkesi'nin şeyhi Şemseddin Efendi halifelerinden Ömer Efendi burada imam iken bu ciheti ondan satın almıştı.

Şeyh Ziya Efendi'nin zikirciliği de kuvvetliydi; kıyam zikrini ayak vurarak idare etmek gibi orijinal tarafları bile vardı, zira ayak vurmak devrana mahsustur.

Sonradan Bektaşîliğe intisap eden Ziya Molla'nın babalık icazesi bidayette Merdivenköy şeyhi Hacı Ahmed Burhan Baba'dandır, sonra ayrıca Çamlıca Tekkesi şeyhi Ali Nutkî Baba'dan da ikinci bir icaze daha almıştır ki rehberi Yaşar Baba'ydı. ${ }^{1}$ Kendisine Hazret-i Hüdâî Hankahı'nda ayrıca ve teberrüken Celvetiyye tâcı da giydirilmişti.

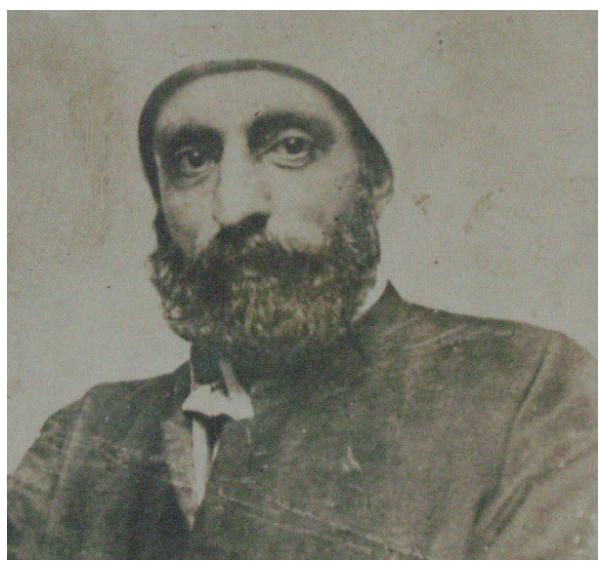

Üsküdar Rifâ‘̂̂ Tekkesi şeyhi Ziya Molla, 1908 civarında (Revnakoğlu arşivinden)

1 Revnakoğlu, klasik tekke musikisinin büyük üstadı dediği, İstanbul'un meşhur zakirbaşılarından Yaşar Baba'nın ayrıntılı biyografisini bazı fotoğraflarla birlikte şu yazılarında kaydetmiştir: Cemâleddin Server Revnakoğlu, "Meşhur Bektaşiler: Yaşar Baba", Tarih Dünyası, C. 2, S. 6, 1965, s. 177-180; Cemâleddin Server Revnakoğlu, "Meşhur Bektaşiler: Yaşar Baba”, Tarih Dünyası, C. 2, S. 7, 1965, s. 251-253. 
Himmetzâdelerden İzmit Bayramiyye Tekkesi şeyhi meşhur Zakir Abdussamed Efendi'nin babasından ders okumuş, onun oğlu Şeyh Abdussamed Efendi'den de bir şeyhe lâzımdır diyerek bir miktar şuul ve ilâhî geçmişti. Abdussamed Efendi'ye "hocam" ve "hocazâdem" diye hitap ederdi. Hocazâde ne zaman dergâha gelse Şeyh Ziya Efendi mihrap önünde hemen feracesini sırtından çıkarıp ona giydirir ve idareyi de ona birakırdı.

Revnakoğlu, Bektaşîliği hakkında kîlükâl edenlere Ziya Efendi'nin söylediği şu ilahiyi merhum Hacı Şeref' in ilahi mecmuasında sayfa 382'den aktarmaktadır:

Gördüm cemâlinde yâ hû rûy-1 Şâh'1 renk renk Mevc urur cismimde rûhum seninle renk renk

Mübtelâ oldum ezelde zuhûr etti bu âlemde Aşkın ile ben her demde görünürüm renk renk

Bildirilmez işte bu hâl söyletmen çünkü muhâl Uşşâkın malûmu fi'l-hâl aşktan görünürüm renk renk

Esîr-i nutk-1 yâr oldum aceb bilmem ne bu hâl oldum Âleme destân oldum söylenirim renk renk

Hâlimi bilenler yoktur vâkıf-1 sırr olan yoktur Hakkımda söyleyen çoktur işitirim renk renk

Renk da'vâsın edenlere renkten haber soranın Andan haber vermezem ben görünürüm renk renk

Rengin aslını bilmeyen şarâb-1 aşkı içmeyen Sâkî-i şarâb-1 aşkım gel iç benden renk renk

Pâzâr-1 aşkı bilmezler sırr-1 Hak'tan anlamazlar Âyîne-i aşktır Ziyâ görünürüm renk renk

Hazretin cenaze namazı dergâhın karşısındaki Tavaşi Hasan Efendi Câmi'-i şerîfinde eda olundu. Vasiyeti üzerine ertesi çarşamba günü tekkede büyük babası Şeyh Feyzullah Efendi'nin lahdinin içine konulmuştur, babasının yanında değildir.

Ayrıca Ziya Efendi'nin söylemiş olduğu bir nefesi Ergun (Ergun, II, 1943: 683-684) şu şekilde kaydetmektedir: 
Bakdım ben ol mihrâba gördüm cemâl-i yâri

Temevvüc etti aşkım verdi bana bu hâli

Ziya sen de sabr eyle erem dersen

Hüseyn'e Fedâ kıl cân ü başın terk et

ucb ü riyâyı

Revnakoğlu, Şeyh Ziya Efendi'nin halifelerini zikrettikten sonra, bu sefer ona "Ziya Baba" diyerek ondan Bektaşî nasibi alanları sıralar: Zakirbaşı Tatar Yaşar Baba, Giritli Postacı Ali Baba, Balçık Tekkesi postnişini Hâlid Efendi ve oğlu Mahmud Efendi, Boşnak Asım Efendi (Giritli Ali Baba'nın oğulluğu), Şeyh Râmiz Baba, Kubbe Tekkesi dervişlerinden Nihad Efendi ve Süleyman Efendi.

Adını kubbeli tevhîdhanesinden alan Kubbe Tekkesi de Rifâ‘îlik'in mühim merkezlerindendi. Revnakoğlu notlarına akseden şu bilgi, bu tekkenin son devrinde Bektaşî neşesini göstermeye kifayet eder (96:5):

Kubbe şeyhi merhum Molla Bey'le Kara Baba şeyhi Hakkâk Mehmed Hilmi Efendi merhum matem ayında hususiyle aş gününde ekseriya Merdivenköy Bektaşî Tekkesi'nde bulunurlar, başlarına fahir geçirerek hizmete soyunurlar ve çok defa dergâhın aşevindeki hizmetin tertip ve intizamına riayet ederler, avdetlerinde beş lira alırlar ve niyaz esnasında rikâp (etek) öperlerdi. Molla Bey'in zaten dedebabadan nasibi vardı. Bu zevatın arasında Beylerbeyi Settâriyye şeyhi Râmî Bey merhumun da bulunduğu olurdu, fakat Râmî Bey şeyhzadeliğinde kendi babası tarafından dedebabanın terbiyesine verilmiş olduğu için başında Bedevî tacı olarak hizmete iştirak ederdi. Bu istisnai müsaade dedebabanın irfan ve insafını gösterir... Molla Bey birazcık demlenirdi, "Az miktarında haramiyyet yoktur" derdi, "İmâm-1 A 'zam sekir vermezse sekirden önceye kadar caizdir" demiş diye de ilave ederdi.

17 Şubat 1910'da vefat eden Molla Bey'in takipçilerinden, halifelerinden bazılarının isimleri ve bunların postnişini oldukları tekkelerin adları zikredildiğinde bu Bektaşî de olan Rifâ‘î şeyhinin kudreti ve meşrebinin nüfuz sahası daha iyi anlaşılır: Kubbe Tekkesi'nin son şeyhi büyük oğlu Haydar Bey, Karasarıklı Tekkesi şeyhi Hasan Safvet Efendi ve son şeyhi Şevket Efendi, Alyanak Tekkesi son şeyhi Kadri Efendi, Çırakçı Tekkesi'nin son şeyhi Bedreddin Bey, Bekâr Bey Tekkesi şeyhi İhsan Bey. Bunlara ilâve olarak teberrüken de kendisinden Âbid Çelebi Tekkesi'nin son şeyhi Selâhaddin Bey ve Resmî Kâdirîhanesi şeyhi Mehmed Şerefeddin Efendi hilâfet almıştı.

\section{Celvetiyye'den:}

Aziz Mahmud Hüdâî tecrübesiyle Halvetiyye ve Bayramiyye'nin içinden çıkan Celvetîlik, "Hâşim Baba” diye ünlenen Mustafa Hâşimî'nin (ö. 1782) tesis ettiği kolda Celvetî-Bektaşî bir renk almış, bu kolun son şeyhi Yusuf Fahir Baba'ya kadar bu meşrep devam etmişti.

2 Nasip almak, Bektaşîliğe intisap etmek demektir. 
Hâşim Efendi, merkezde Celvetî şeyhidir, diğer birçok şahsiyette olduğu gibi Bektaşîlik onda ikinci derecede ve tarikat erkânına tesir etmemiş bir hâldedir. Çok defa tekkeler devrinin son safhasında bu renge bürünen bazı tarikat şeyhlerinde Bektaşîlik, ayinlerine, adaplarına dahil olmadan, ancak neşesiyle, Hz. Ali ve evlâtlarına duyulan muhabbetle, kalenderlikle temsil edildi. Revnakoğlu bu hususa Hâşim Baba'ya dair notlarında bilhassa işaret eder (90:316):

Tarikat mensuplarının "Seyyid Hâşim" dediği, Bektaşîlerin "Hâşim Baba" diye tanıdığı bu zat, esasında Celvetiyye'dendir. Bu tarikatta "Hâşimiyye" şubesini kurduğu için ikinci pîr sayılır. Bazı şiir ve akidelerinde meşreben Bektaşilikle ilgisi olduğu görülürse de bu onun izafe tarafıdır, kendisine ve kendisinden sonra tekkesinde şeyhlik edenlere usulen verilmesi âdet olan itibarî bir Bektaşîliktir ki nisbî bir tevcihten, formaliteden ibarettir. Seyyid Hâşim'in Üsküdar'daki Bandırmalı Tekkesi'nde kendi zamanından beri tatbik edilegelen bu usul yani Seyyid Hâşim'in çocuklarına ve buranın şeyhlerine Bektaşîyye'den icazetname verilmesi zamanımıza kadar ihmal olunmaz bir anane hâlinde devam ettirildiği hâlde bu tekkenin şeyhleri şimdiye kadar hiçbir Bektaşî dergâhında babalık etmiş değillerdir; Bektaşîlerce de gerçek bir Bektaşî babası sayılmazlar, çünkü emeksiz, hizmetsiz, sûrî bir şekilde verilen teberrüknameden ibarettir.

Haşim Baba’nın Bektaşilik intisabının kimden olduğu konusunda Ergun şunları kaydetmiştir:

“... Kırşehir'deki Hacı Bektaş Tekkesi babasının İstanbul'daki vekili idi. Üsküdar'da Celvetiye'den Bandırma dergâhı şeyhi olmakla beraber Mısır' daki Kasrülayn tekkesi şeyhi Hasan Baba’ya intisab ederek Bektaşi olmuştu.” (Ergun, II, 1943: 409)

Nakşibendiyye dışındaki Sünnî tekkelerde Bektaşîliğe karşı duyulan taassup ancak 19.yy'ın ikinci yarısında çözüldü. Hâşim Baba, daha erken bir tarihte Bektaşî olmuş ve bedelini de bilhassa vefatından sonra ödemişti. Cenazesi onun Bektaşîlik cephesinden huzursuz olan Celvetîlerce asitaneye alınmamış, tekkeler tarihinde ilk vaka olarak bu hadise unutulmamıştı. Celvetî asitanesince "Bektaşî", dinden uzak kimsenin; "Bektaşîlik" dine muhalif hâllerin adıydı. Bu umumî duruştan ilk ayrılan Celvetî Bandırmalı Tekkesi şeyhi Seyyid Hâşim’in vaziyeti, "Hâşimiyye musallâsı" denilen bir müşahhas mekânın varlığıyla da tescillenmişti (208:410-16):

Hâşimiyye musallâsı, Hazret-i Hüdâî Hankahı'na gelirken cümle kapısına ve yanındaki çeşmeye varmadan dört yol ağzındaydı. Seyyid Hâşim vefatında cenaze namazı kılınmak üzere hankaha getirildiği zaman kapılar kapanmış, cenaze içeriye alınmamıştır. Sebep, Seyyid Hâşim'in aynı zamanda Bektaşî olması ve Hacı Bektaş Hankahı'nda dedebabalık etmiş bulunmasıdır. Bunun üzerine cenazeyi getiren Seyyid Hâşim Tekkesi mensupları ve hazır bulunan diğer şeyhler ve dervişler Celvetî usulüne başlamışlar; bir kısmı da hemen orada bir musallâ makamı vücuda getirmeye koyulmuşlar. Yeni musallânın yapılması bitip tamam oluncaya kadar tabutun etrafinda toplu bir hâlde yapılan Celvetiyye usulü devam etmiştir ve ancak bundan sonra Seyyid Hâşim'in cenaze namazı burada kılınmak suretiyle Bandırmalı 
Tekkesi'ne getirilmiştir. Bandırmalı Dergâhı şeyhlerinin cenaze namazlarının bu musallâda kılınması böylece sünnet-i tarîkat olmuştur. Hazret-i Hüdâî Hankahı'nın son şeyhlerinden Ruşen Bey iki dergâh arasındaki geçimsizliğin unutulması için musallâyı oradan kaldırtmıştır ve çok da iyi etmiştir.

Celvetî şeyhlerinden Sarmaşık Tekkesi'nin son şeyhi ve Mihrimah Camii imamı Hafız İbrahim Hakkı Efendi'nin gasli Bektaşî Râmiz Dede tarafından gerçekleştirilmişti. Sarmaşık Tekkesi, Celvetîlerce (117:444) "Hazret-i Hüdâî burada birkaç gün oturdukları ve dolayısıyla meydan açıp mukabele ettikleri için âsitâne-i sânî sayılır."

\section{Halvetiyye'den (Sinâniyye-Zühriyye)}

Sarmaşık Tekkesi’nin Celvetî şeyhlerinden Hafız İbrahim Hakkı Efendi’yi gasleden Râmiz Dede, Halvetiyye'nin Sinâniyye-Zühriyye kolu şeyhlerindendi. Sonradan dahil olduğu Bektaşîlikte babalık mertebesine erişmişti. Tam adı "Salih Râmiz Coşkun Eren" olan ve "Râmiz Baba", "Müftü Baba" diye de bilinen bu şeyhin biyografisi, kendisine devam eden Revnakoğlu tarafından kaleme alınır (232:63-64):

H.1286'da Selanik'te Sinânî Tekkesi'nin yanındaki baba evinde doğdu. Zâkirzâde Şeyh Mehmed Necip Efendi'nin oğludur ve onun babası Derviş Salih Efendi, babası Emin Efendi, babası Mehmed Efendi, babası Mahmûd Efendi, babası Ramazan Efendi (Akâid şarihi; İstanbul'dan Selanik'e gitmiştir.)

İlk defa Selanik Cami-i kebîr hatibi Abdülkerim Efendi'den besmele dedi, sonra Hamidiye isimli ibtidaî mektebine girdi; bitirdikten sonra rüşdiyeye geçti, onu da ikmal ettikten sonra fikha başladı ve 18 yaşında tamamladı, icazeti yine Abdülkerim Efendi'dendir. Daha sonra İshak Paşa Medresesi müderrisi Hafız Abdullah Efendi'den cami dersleri okudu, 23 yaşında icazetname aldı.

Tarikat tarafi: Sinânî Zühriyye'den Salih Lutfi Efendi hulefâsından Nevrekoplu Şeyh Mehmed Efendi'yedir. Şeyh Mehmed Efendi'nin ecdadı, Zühriyye'den Nevrekop Tekkesi'ni yapan Şeyh Yakup Efendi'dir. Bu Yakup Efendi, Hüsameddin Uşşâkî halifelerindendir.

Sülûkunu bitirip Serez'de Cuma Tekkesi şeyhi Serezli Hüseyin Efendi'den istihlâf edildi, 25 yaşındaydı. Pederi hayatta olduğundan tekkede şeyhlik etmedi, kendi tekkesinde ve diğer dergâhlarda zaman zaman zakirlik, zakirbaşılık ederek, bazen de meşkler yaparak hayli talebe yetiştirdi. Ramazâniyye'den de icazesi vardır.

Selanik Hamidiye Câmi'-i şerîfinde uzun müddet imamlığı vardır. Bu vazife üzerinde iken Lankaza müftüsü seçildi, Yunan işgaline kadar 25 sene müddetle bu vazifede kaldi.

Bektaşîliği: İlk nasibi İzmir'de Hüseyin Hâkî Baba'dandır. 1948'de İstanbul'da Zenneci Hasan Basri Baba'dan dervişlik ve baba tâcı giydi. Marangoz Üsküplü Ziya 
Baba ile beraber Postacı Ali Baba tarafindan destarı sarılıp icazetnamesi verildi; rehberi Ahmed Necmeddin Baba'dır.

Vefatı 27 Kasım 1962 salı saat 18.30'da. İki gün sonra regaip kandiline rastlayan perşembe günü toprağa verildi. Bakırköy Akıl Hastahanesi'nde göçtü. Rûmî 14 Kasım 1377, 29 Cemaziyelahir.

Revnakoğlu, yukarıdaki resmî notlarına, yakından tanıdığı bu babayla ilgili şahsî malûmat da ilâve eder (232:66-69):

Salih Râmiz Baba, Zenneci Hasan Basri Baba'dan tâc giymiş, Postacı Giritli Ali Cemalî Baba'dan icaze almıştır. İlmi, fazlı, hâli, kemali ile yaşayan kıdemli babalar içinde "dedebaba" değil, "pîr baba" sayılacak kâmil insandır. Mükemmel ve mükemmildir; bulunmaz, erişilmez meziyetlere malik, gün görmüş, umur görmüş, hâl ehli, sevimli bir ihtiyardır. Hem ilmiyeden hem meşâyihten hem de Nâzeniyye'den bulunması Tanzimat'tan beri İstanbul Bektaşî babaları arasında pek az görülen hususiyetlerindendir.

Zaman zaman hafız ve imam, Selanik'te müderris, Lankaza müftüsü ve Halvetiyye'nin Sinânî - Zührî kolları şeyhi iken son zamanlarda Bektaşî olmuştur. Hayatta bulunan son babalar içinde irfan adamı olmak itibarıyla hakikaten üstün bir yeri vardır ki kimse tarafından istihlaf edilemez. Yaşının bir hayli ilerlemiş olmasına rağmen kitap ile ilimle ilgisi hâlâ kesilmemiştir. Şaşılacak şekilde hafıza kudreti, gayetle mazbut, esaslı bir vukufun mahsulü olan meslekî malûmatı, hele o eşsiz emsalsiz mahfuzat ve hatıratının zenginliği, dolgunluğu, yaşının doksana dayanmış olmasına rağmen hiç yaşlanmayan, hakikaten imrenilecek müstesna bir mazhariyet hâlindedir. Zaten babanın ayakta duran en kuvvetli tarafi da budur.

Her hâlini iyi bildiğim eski bir aşina olması itibarıyla diyebilirim ki eli kalem tutan, eser veren bir fikir ve kültür adamının onunla konuşması, eserine en sağlam vesikayı, en zengin hazineyi bulmuş olması demektir, çünkü ne söylediyse kitapta yeri vardır. Onun bu hâlini velînimet-i irfânımız merhum ve magfur Allâme İsmail Sâib Efendi hazretlerine benzetirdim, rûh-1 revânı şâd u hurrem olsun.

Fakat Ramiz Baba'nın affolunmaz bir hatası vardır, geçen yüzyılda tekke şeyhlerinin içine düştüğü, tekkeleri çöküşe ve kapanışa sürükleyen bir günahtır bu (232:48-49):

Râmiz Baba'nın, bu irfanlı, faziletli adamın son günlerinde bence en büyük hatası, hatta kabahati şu olmuştu: Hiç bilmediği, tanımadığı, konuşmadığı, sadece kahve köşesinde rastladığı her telden çalar, her yolda görünür bazı kimselere Mazlûm Baba'nın rica ve tavsiyesine inanıp daha doğrusu ömründe erkân görmemiş, erkâna girmemiş bu adamlara kendi icazetnamesinden birer suret çıkarıp dağıtması ve dolayısıyla evliyâullâhın emanetini ziyan, sebil etmesidir. Kendisinden sonra onların baba rolünde görünmeleri işlenmiş bu büyük hatanın acıklı bir sonucudur. 


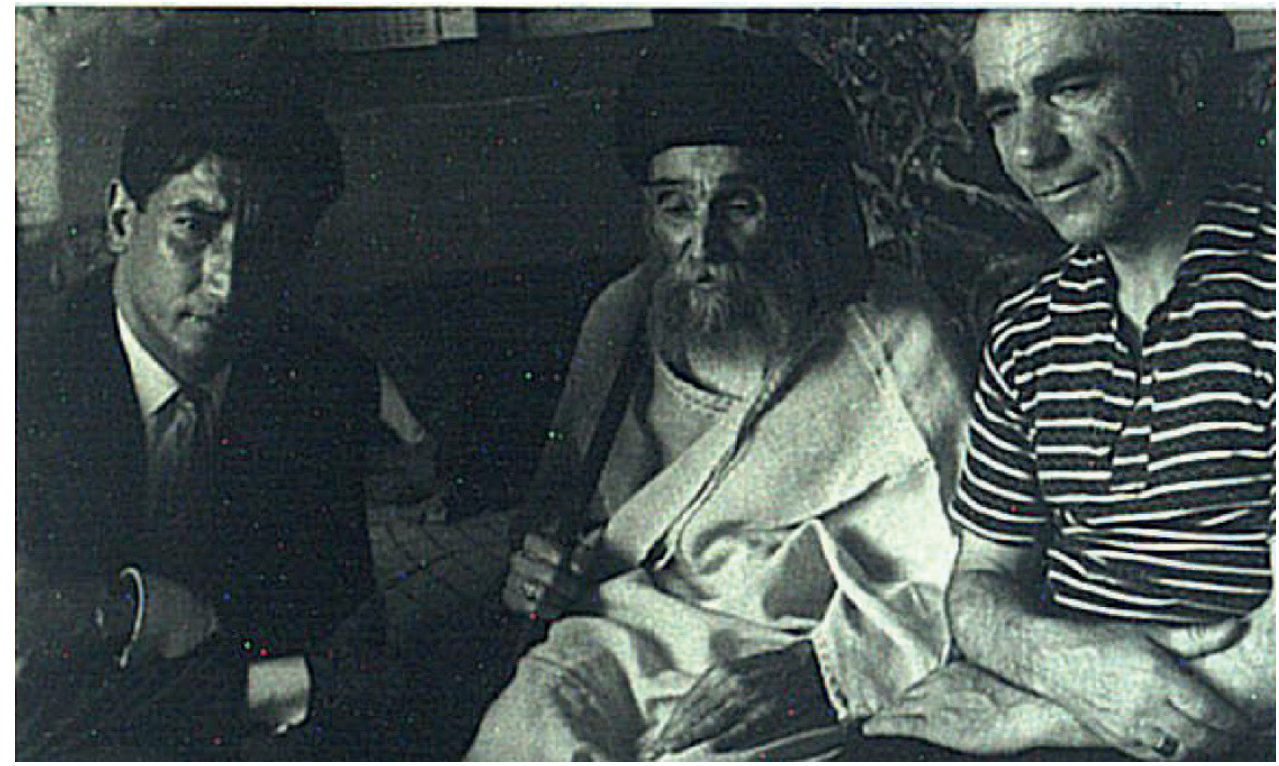

Ortadaki Râmiz Baba, sağdaki Revnakoğlu

\section{Mevleviyye'den:}

Geçen yüzyılın başında, Abdülvâhid Çelebi, Mevlevîlikte Bektaşî rengin en yoğun olduğu şahsiyetti, aldığı hilâfetle Bektaşî nasibi de veriyordu. Revnakoğlu notlarına göre Abdülvâhid Çelebi (ö.1907), Bektaşîlik ikrarını Mehmed Ali Hilmi Dedebaba'dan, nasibini de Nâfi' Baba’nın halifelerinden Ruhî Baba'dan almıştı (269:157-60):

Abdülvâhid Çelebi, İzmirli Ruhî Beybaba'dan Bektaşî nasibi almıştı, bu itibarla kendi oğlu ve cânişîni olan Abdülhalîm Çelebi'yi de Bektaşî yapmıştı, ayrıca çelebiyândan bazılarına ve Mevlevî muhibleri arasında müstaid gördüklerine Bektaşiyye'den nasip veriyordu, bu sebeple Bektaşîlik ve Bektaşîlerle alâkası artmıştı. Kırşehir'de Hacı Bektaş makamını ziyaret etmek üzere Aksaray'a kadar gitmişti, orada Sultan Abdülhamîd tarafindan Konya'ya sürgün gönderilen hürriyetperver zevat ile temasa geçerek onlara maddî-manevî yardımlarda bulunuyordu.

Üçüncü hanımı için Konya'nın Meram sayfiyesinde yaptırdığg köşküne de "Yıldız" adını koymuştu. $\mathrm{Bu}$ derece ileriye gitmek cesaretini göstermekte devam ettiğinden saray kendisinden pek tabiî olarak hoşlanmıyordu. Şehrin valisi bulunan Avlonyalı Ferid Paşa'nın da bu hâl dikkatini çektiğinden o da üzüntü ve endişe içindeydi. Kendisi nasipli bir Bektaşî olduğu hâlde biraz da kıskançlık yüzünden Abdülvâhid Çelebi'yi çekemiyor ve onun Bektaşîliğini saraya karşı menfi bir hareketmiş gibi göstermek istiyordu. Nihayet Abdülvâhid Çelebi'ye oyun etmek için saraya şu mübalağalı telgrafı 
çekti: "Konya pîr makamı postnişini Abdülvâhid Çelebi, Aksaray'da birkaç yüz Bektaşî babası ile halvet olmuştur. Şimdi de Acem'e doğru hareket etmek üzeredir!"

Ferid Paşa'nın bu telgrafı vehm-i şâhâneyi artırmış olduğundan hemen şu cevap gelmişti: Abdülvâhid Çelebi'nin derhâl Acem'den geri çevrilmesi ve Konya şehrinden dışarıya çıkmaması irade ediliyordu.

Hâlbuki Abdülvâhid Çelebi, Aksaray'dan Hacı Bektaş'a girerken yol üzerindeki Acem köyüne hâliyle uğrayacağından Ferid Paşa vehm-i şâhâneyi tahrik etmek için buradaki "Acem" lafzı ile Acemistan'a gitmek üzere bulunduğunu ortaya atarak zihn-i şâhâneyi teşviş etmek istiyordu.

Bezmi Nusret Kaygusuz, Revnakoğlu’na yazdığı 1960 tarihli mektubunda Abdülvâhid Çelebi’nin Bektaşî şeyhi Ruhî Beybaba için şu bilgileri verir (248:77):

Ruhî Beybaba'ya gelince, 1828'de İstanbul'da doğmuştur. Babası Abdülmecid'in saray imamı ve şehzadelerin muallimi Kazasker Mehmed Zeynelabidin Efendi'dir. Arapça, Farsça ve Fransızca bilirdi. Edirne ve Bağdat vilâyetlerinde kadılık yapmıştır. Sultan Murad taraftarı diye Abdülhamid tarafından İzmir'e sürgün edilmiştir. İzmir'de avukatlık da ederdi. Nâfi' Baba'nın yetiştirmelerindendir. Zarif nükteleriyle büyük bir şöhret kazanmıştır. Şair Eşref, mebus ve bestekâr Şükrü Şenozan, Taşlığlu Doktor Edhem, muharrir ve müellif Bıçakçızâde Hakkı, meşhur Tevfik Nevzad, Zeytunîzâde Remzi ve daha birçok efâzıl bu zattan nasip almışlardır. 1899'da İzmir'de vefat etmiştir. Sanırım ki bazı fikra ve nükteleri Ziya Somar'ın Fikir ve Edebiyat Tarihimizde İzmir [Yakın Çağların Fikir ve Edebiyat Tarihimizde İzmir] adlı eserinde zikredilmiş olacak.

Revnakoğlu, Bezmi Nusret'e yazdığg cevabî mektubunda yukarıdaki biyografik malûmatın bir kısmını tashih edip ilâvelerde bulunur (248:79):

Yalnız bir noktayı arz edeyim: Ruhî Beybaba, Zeynelabidin Efendi’nin oğlu değil, torunudur. Zeynelabidin Efendi, “Zeynî Efendi” denilen zattır ki Molla Gürani’de Reisületıbba Ömer Efendi Medresesi’nde yatan Şeyhülislâm Çelebizâde Küçük İsmail Asım Efendi'nin oğlunun oğludur. İsmail Asım Efendi, biliyorsunuz, aynı zamanda şairdir, divanı vardır, vakanüvistir; baba - torun kazasker ve şeyhülislâm olmuşlardır. Molla Gürani Tekke ve haziresinin karşısındaki medresenin bahçesinde ailesi efradı ve şair kızı ile beraber yan yana yatıyorlardı. Bu hasta heriflerin tarihî ismetimize saldıran istimlâk tahripleri sırasında 1959 Ağustosunda bir gece içerisinde havaya uçuruldu. Bereket versin, kitabelerini yıllarca önce yazmıştım.

Tekrar başa dönelim, Abdülvâhid Çelebi’nin Bektaşî ikrarına ait vesika, bizzat ikrarnamenin metniyle Revnakoğlu dosyalarında yer alır. İkrarnamenin sonunda Hasan Sait Bey'in babası Osman Nuri Bey'in el yazısı ve imzasıyla şu not yer alır: "Abdülvâhid Çelebi, Manisa Mevlevîhanesi şeyhi iken mürşidim Mehmed Ali Hilmi Dedebaba’yı oraya davetle nasip 
aldığını müşarünileyhin vekîl-i umûru olup 1341 senesi görüştüğüm Manisalı Agâh Bey’den öğrendim. Vâhid Çelebi sonra baba olmuştur. Bu ikrarnameyi kendi tanzim ettiği anlaşılıyor. Ben bunu kerimezâdesi Said Çelebi’ye evrakı arasından aldırmıştım. Nevruz"

İmzasını tayin edemediğimiz aynı evrakın arkasındaki bir diğer notta da bu vesika için şu ifadeler yer alır: "Tarîkat-i Bektaşiyye'den olduğu mervi bulunan evlâd-ı Hazret-i Mevlana'dan ve Konya Asitâne-i Mevleviyyesi postnişini merhum Abdülvâhid Çelebi’ye ait ikrar ve ahidnâme-i Bektaşiyye olarak rivayet edilerek fakire getirilmişti. İkrârnâme-i Bektaşiyye ile hiçbir müşareket olmayan bu suret, Said Bey'le ayrıca müzakere edilerek bu zan tashih edilecektir. 14 Mayıs 1326."

Revnakoğlu'nun, dostlarından Hasan Said Çelebi'nin vefatından sonra babası Nevruz Bey'den aldığı Abdülvâhid Çelebi'ye ait ikrarnamenin her hâlde suretten ibaret olan metni şöyledir (180:15-18):

\section{Bism-i Şâh}

Erenler meydanında pîr huzurunda mürşidine teslim ve rızada oldun mu? Oldum. Kazaya razı olup kadere bağlandın mı? Bă̆landım.

Ettiğin ahid ve ikrardaki esrarl agyara söyleme! Allah, Muhammed, Ali ve on iki imam hânedân-l ehl-i beyte iman ve ikrar ettin mi? Ettim.

Zikrolunacak ahidnamede münderiç olan şerâyitin kâffesini kabul edip mucebince amel ve sebat etmediğin surette haremin talâk-l selâs ile boş olsun mu? Evet, şerâyitin mündericatın kâffesini kabul edip mucebince amel ve sebat etmediğim surette haremim talâk-l selâs ile boş olsun.

Ve bu kabul ve ikrardan döner isen rûz-i mahşerde yüzün kara olsun mu? Olsun.

Hazret-i Peygamber sallallâhu aleyhi ve sellem ve Cenâb-ı Ali Murtazâ kerremallâhu vechehu efendilerimizin ve evlât ve ahfâdının sevdiklerini sevip tevellâ ettin mi ve sevmediklerini sevmeyip teberrâ ettin mi? Ettim.

Sevilmeyecek şunlardır: İbn Mülcem, Şimr-i Zi'l-cevşen, Muaviye, Yezid, Ubeydullah b. Ziyad, Amr b. el-Âs, Mervan, vaka-i Kerbelâ'da a'dâ askerinin serdarı Habîs-i Ömer ve o askerin kâffesi, el-hâsıl Yezid'in oğlu Küçük Muaviye ile Ömer b. Abdülaziz'den başka Emeviyye gürûh-l mekrûhunun kâffesi ve bu habislere lanet olsun mu? Olsun.

Ve bu ahbeslerden başka Hazret-i Şâh-l "levlâk" ve Cenâb-l Şâh-l velâyet efendilerimize ve evlât ve ahfâdına ihanet edenleri tevârîh ve kütüb-i sâirede gördükte ve hakikatine vâkıf olanlardan işittikte sevmeyeceksin! Sevmeyeceğim.

Zikrolunacak ahidnamedeki şerâyitin kâffesini kabul ve mucebince amel ve sebat etmezsen İbn Mülcemliği, Şimrliği, Mervanlı̆̆l, Muaviyeliği, Yezidliği, Nemrudluğu, Firavunluğu, Ebucehilliği kabul ettin mi? Ettim. 
Ve şerâit-i mezkûrede sebat etmezsen Cenâb-l Hakk'ı ve peygamberimiz Hazret-i Muhammed sallallâhu aleyhi ve sellemi ve kâffe-i peygamberân-ı izâmı ve Hazret-i Ali kerremallâhu vechehu efendimizi ve Imam Hasan ve Imam Hüseyin efendilerimizi ve kâffe-i evlâd-ı Resûl'ü ve pîr-i destgîrimiz Hazret-i Mevlana Celâleddin Rûmîve Hazret-i Şems-i Tebrizî ve Hacı Bektaş-ı Velî efendilerimizi ve kâffe-i pîrânı inkârı kabul ettin mi? Ettim. Vallâhi mi? Vallâhi. Billâhi mi? Billâhi.

Zikri mev'ûd ahidname ve şerâyit:

Allahu taâlâ ve tekaddes hazretlerinin birliğini tasdik ettin mi? Ettim elhamdü lillâh.

Kur'ân-ı kerîmde olan enbiyanın kâffesinin ve bâ-husûs Fahr-i âlem sallallâhu aleyhi ve sellem efendimizin ve bi'l-cümle enbiyanın nübüvvetlerini kalben ve lisanen tasdik ettin mi? Ettim.

"Lahmüke lahmî, cismüke cismî̀" hadîs-i şerîfinden müstebân olduğu veçhile Hazret-i Muhammed ile Cenâb-ı Ali'yi bir bildin mi? Bir bildim.

Pençe-i âl-i abâ olan Muhammed, Ali, Fatma, Hasan, Hüseyin efendilerimize muhabbet, Allah'a muhabbettir ve bu zât-l şerîflere ziyade muhabbet edip her işte kendilerinden istimdat edecek misin? Edeceğim.

Imam Ali ve Hazret-i Fatma ve Hazret-i Hasan ve Hazret-i Hüseyin ve Hazret-i Zeynelabidin ve Muhammed Bakır ve Cafer-i Sâdık ve Musa el-Kâzım ve Ali Rıza ve Muhammed Takî ve Ali Nakî ve Hasan el-Askerî ve Muhammed Mehdî efendilerimizi ve on dört masum pâkı kâffe-i ashâbdan ziyade sevdin mi? Sevdim.

Ve bu zevât-ı kirâmı Ebu Hanife ve Şâfi'î ve Malik ve Ahmed b. Hanbel'e tercih ettin mi? Ettim. Haticetü'l-Kübrâ'yı ve sair evlâd-ı inâs-ı Resûl'ü kâffe-i nisâya tercih ettin mi? Ettim.

Eimme-i isnâ aşer ve on dört masûm-l pâkten sonra pîr-i destgîrimiz Hazret-i Mevlana ve Hazret- $i$ Şems-i Tebrizî ve Hacı Bektaş-ı Velî efendilerimizi kâffe-i [yırtık olduğu için okunamadı] bildin mi? Bildim.

Mâniin olmayıp Konya'da bulunulduğu hâlde hiç olmazsa ayda bir kerre pîr-i destgîrimiz Hazret-i Mevlana efendimizin huzûr-l şerîflerine yüz sürüp ziyaretiyle teşerrüf edecek misin? Edeceğim.

Ve ziyaret esnasında hademe-i bâb-l saâdet bulunanlara üç yüz kuruş nakde malik isen dokuz kuruş niyaz verecek misin? Vereceğim.

Ve Hazret-i Şems-i Tebrizî efendimizin hiç olmazsa iki ayda bir kerre zikrolunan üslûp üzere ziyaretiyle teşerrüf edecek misin? Edeceğim.

Ve sair ehlullâh-ı kirâm ve ehl-i kubûrun ziyareti re'yine muhavveldir ve ziyarette muhsenât çoktur. 
Ve deyninden başka eli altmış bin kuruşa malik olduğun hâlde Kerbelâ'yı ve şâh-ı Necef'i ziyaret edecek misin? Edeceğim.

Vücudun afiyette olmak şartıyla ve deyninden maada on bin kuruşa malik olduğun hâlde Hacı Bektaş-ı Velî hazretlerinin ziyaretine gidip bin kuruş sarf edecek misin? Edeceğim.

Paraya bakmayarak bu ziyaretgâhlara arzu olunursa mütevekkilen gitmeye mezunsun ve re'yine muhavveldir, ama hac bahsinde şer'-i şerîf mucebince amel etmekle mükellefsin ve savm ve salât ve zekâtta dahi muktezâ-yl şer'le amel etmeye memursun. Beher gün öğlenden evvel kıbleye müteveccihen Nâd-ı Ali ve fâtiha-i eimme-i isnâ aşere abdest ile devam edecek misin? Edeceğim.

Hasbe 'l-beşeriyye mâni'-i şer 'îzuhur etmedikçe terk etmeyecek misin? Etmeyeceğim.

Ve kasden haftada iki defa terkinde beis yoktur, tarafimızdan izin verilen ism-i celâle devam edip ism-i celâl nihayetinde bildiğin ayetlerden istediğin kadar okuyup pençe-i âl-i abâya ve eimme-i isnâ aşer ve on dört masûm-ı pâk hazerâtının ve Hazret-i Mevlana ve Hazret-i Şems-i Tebrizî ve Hazret-i Bektaş- - Velî efendilerimizin ve hulefâ-yı Mevleviyye ve çelebiyânın kâffesine ve hulefâ-yı Bektaşiyye ve kâffe-i ehl-i îmânin ve ebeveynin ervâh-ı tayyibelerine hediye edip bir miktar Hazret-i Pîr-i destgîr efendimizin sandîka-i şerîfelerine teveccüh ve rabitadan sonra şu veçhile gülbank çekmeli: "Vakt-i şerîf hayrola, hayırlar fethola, şerler defola, Allâhu azîmü'ş-şânın ism-i zâtının nuruyla kulûbümüz pür-nûr ola, dem-i Hazret-i Mevlana, ser-i şems-i nûr-ı nebî, kerem-i Imam Ali, hû diyelim hû.",

Muharremü'l-harâmda avam gibi olmamalıdır. Muharremü'l-harâmın ibtidasından on ikinci gününe kadar sâim olacaksın! Olacă̆ım.

Vücudun afiyette olup hiçbir mâniin yok iken ufak bir bahane ile Muharremin on iki günü içinde kasdî bir oruç yersen Hazret-i Pîr-i destgîr efendimizin dergâh-l şerîflerinde tâmmü'l-a'zâ ve semiz koyun kurban kesip otuz altı ya on sekiz yahut dokuz kuruş tuz mangırı vereceksin! Bir koyun kurban kesip tuz mangırı dahi vereceğim.

Ve tekrar bir oruç dahi yersen Hazret-i Şems efendimizin dergâh-l şerîfinde bervech-i mezkûr bir koyun keseceksin! Keseceğim.

Kasdî olarak iki oruçtan ziyade yersen aslâ tecviz olunmayıp merdûd olup Yezidliği kabul edeceksin! Muharremde on iki gün içerisinde iki oruçtan ziyade yersem merdîd olup Yezidliği kabul edeceğim.

Bir dergâhta yahut muhibbândan birinin hanesinde mersiye yahut Hadîkatü's-Suadâ okunursa vücudun afiyette olduğu hâlde devam edeceksin! Edeceğim.

Bir mühim iş sebebiyle on iki gün içerisinde iki yahut üç defa bulunamazsan beis yoktur. Hanende mersiye yahut Hadîka veyahut sair ehl-i beyt ve evlâd-ı Resûl'e müteallik kitapları okumak ve okutmak muvâfik-ı tarikattır, binaenaleyh ihtimam 
etmelidir. Mersiye ve Hadîka ve evlâd-ı Resûl haklarında olan sair kitaplar okunurken kemâl-i ta'zîm ile dinleyeceksin! Dinleyeceğim.

Dizin ăgrımaz ise dizini kaldırmayacaksın! Kaldırmayacă̆ım.

Dizinde ustırap var ise sandalyede oturmaya ve bağdaş kurmaya mezunsun. Muharremin on iki günü zarfinda az gülmeli, az yemeli ve esnâ-yı slyâmda çorba ve mevsimine göre biraz sebze yemelidir. Et yemeyeceksin! Yemeyeceğim.

Çorba ve sebzeyi her nevi yağla pişirtmeye mezunsun, yalnı kıyma yerine yumurta kullanılacaktır. Ekmeği bıçak ile kesmeyeceksin! Kesmeyeceğim.

Bu on iki gün zarfinda siyah elbise giyeceksin. Eğer siyah elbisen yok ise alt yüz kuruşa malik isen siyah elbise kestireceksin! Kestireceğim.

Eyyâm-ı sâirede mavi giymemeye dikkat edeceksin! Edeceğim.

Abâ gibi yünden mamul elbise giyeceksin. İntisap ettiğin kıtmîr-i âl-i abâ mürşidin fakire ber-vech-i sadâkat, hulûs-i kalble muhabbet edeceksin! Edeceğim.

Aleyhimde kalben ve lisanen bulunmayacaksın, aleyhimde bulunan olursa müdafaa edeceksin!

Edeceğim.

Aleyhimde bir şey işitirsen gelip söyleyeceksin! Söyleyeceğim. Mürşidin fakiri peder bileceksin! Bileceğim.

Evlât ve ayalimize kem nazar ile bakmayacaksın! Bakmayacă̆ım.

Tarafimızdan halife nasbolunacak olursa fakire olan teslimiyet ve ahd ü misak muamelesini ona dahi edeceksin! Edeceğim.

Ĕ̆er sana bu fakir tarafindan, Allah erenler göstermesin, zuhur ederse ve gittikçe tahakkuk ederse bi'l-müdafaa muhâfaza-i hukûkuna mezunsun. Sen fakiri peder bildiğin gibi fakir dahi seni evlâtliğa kabul ettim ve evlât ve ayaline kem nazar ile bakmayacă̆ım, Allah erenler şahit olsun!

Bu ahidname mucebince intisap edip sırdaşın olan karındaşlarına muavenet edeceksin!

Edeceğim.

Irzına, malına ve canına suikast ve ihanet etmeyeceksin! Etmeyeceğim.

İhvanın ve mürşidinin haremlerine büyük ise valide, akran ise hemşire nazarlyla bakacaksin!

Valide ve hemşire makamında bakacă̆ım.

Deyninden ve havâyic-i zarûriyyenden maada nukûda malik isen hîn-i hâcette 
ihvanının zaruretini bitireceksin, şöyle ki ihvanından biri karz tarikiyle senden bir miktar mangır ister ise beş yüz kuruş nakde malik isen elli kuruş ve bin kuruş nakde malik isen yüz kuruş, hasılı ne kadar nakde malik isen bu hesap üzere binde yüz kuruş vereceksin! Vereceğim.

Ama ihvanından üç dördü birden ister ise içlerinden hangisi ziyade muhtaç ise ona vereceksin!

Vereceğim.

Ve karz-ı şer'îde verilen vade tamamında müstakriz olan zat deynini eda edemediğ $i$ hâlde bir o kadar daha vade... [sayfa eksik]

...ziyaretiyle, sâniyen ihvanın kıdemlilerini ziyaret ve bir kahve veya şerbetini içerek "Yevm-i meserretiniz mübarek olsun” diye tebrik edeceksin! Edeceğim.

Ve yevm-i mezbûrda ihvanından ziyaretine gelenlere riayet edeceksin! Edeceğim. Ve yevm-i mezkûrda yeni elbisen mevcut ise giyeceksin! Giyeceğim.

Hiç olmazsa çamaşır değişip temiz ve pak elbise giyeceksin! Giyeceğim.

Ve yevm-i mezbûra kabil ve vakit müsait ise sahra edip o veçhile icrâ-yı meserret etmek re'yine muhavveldir.

Bu ahidnameye vâklf olmayıp ikrarl olmayan ehl-i zâhire, evlât ve ayal ve karındaşından maadasına kalben muhabbet etmeyeceksin! Etmeyeceğim.

Fakat muktezâ-yı mâ̧şet-i dünyâ icap edenler ile müdara yolunda resmen görüşülür ise beis yoktur. Din ve tarikimizi muhafaza eden halîfe-i rûy-i zemîn padişahımız efendimize kalben, fiilen muhabbet edeceksin! Edeceğim.

İzdiyâd-l şevket ü şân ve ömr-i hümâyûnlarına beher gün dua edeceksin! Edeceğim.

Bilcümle turuk-l aliyyenin ayin ve erkânına dahl ve taarruz edenlere, bâ-husûs Birgivî Hoca ve Berîka sahibi Hâdimli Hoca gibi musannıfin-i bî-insâflara muhabbet etmeyeceksin! Etmeyeceğim.

Ve hâlen mevcut olan ulemâ-i zâhirden bunlara tabi olup turuk-ı aliyye aleyhinde bulunanlara dahi muhabbet etmeyeceksin! Etmeyeceğim.

Erkân bahsine gelelim:

Mürşidinin veyahut ihvanının bulunduğu meclise dahil olduğunda ĕger ehl-i zâhirden ihtiraz olunacak kimse o mecliste bulunmazsa iki elini beline koyup başını ĕgmeli ve münasip yere oturup otururken yeri öpmeli, eğer sandalye üzerine oturulursa tabî öpülmez. Ba'de'l-kuûd aşk alıp münasip muhabbet arzu eder isen söylemeli ve icap eder ise dinlemeli.

Ihvan meclisinde veya kendi hanende veyahut diğer mahalde bulunduğun hâlde sofraya oturuldukta taama tuz ile bed' etmeli ve nihayetinde dahi tuz ile hatm 
etmeli... Ihtiraz olunacak kimse bulunmazsa şu veçhile gülbank çekmeli: "el-Hamdü lillâh, Hak berekâtını vere, erenlerin nân ve keremleri müzdâd ola, dem-i Hazret-i Mevlana, kerem-i İmam Ali, hû diyelim hû.

Ve daimî surette ateş ve kibrit bulunduğu hâlde çerağdan sigara yakmamalı. Elini yuduğun lĕgene tükürmemeli, ateş ocă̆ına tükürmemeli.

İhtiraz olunacak kimse bulunmadiğı hâlde “Bism-i Şâh” deyip taama bed' etmeli. Hanende pençe-i âl-i abâ levhasını bulundurup yüksek mahalle talik etmeli. Ve Cenâb-ı Pîr-i destgîr efendimizin ism-i şerîfi yazılı levhayı dahi bulundurmalı. Sair levhaların bulunup bulunmaması re'yine muhavveldir.

İste bu zikrolunan şerâyit ve erkânı tamamıyla icra edeceksin! Edeceğim. Bıyı̆̆ını kestirmeyeceksin! Bıyı̆̆ımı kestirmeyeceğim.

Cenâb-ı Hak evlât ihsan ettiği hâlde zükûr ise Mehmed Ali ve evlâd-ı Resûl'ün zükûr isimlerinden; eğer inâs ise Hatice ve Fatma ve sair evlâd-ı Resûl'ün inâs isimlerinden ad koyacaksın! Koyacă̆ım.

Bu ahidnamede münderiç olan şerâyit ve erkânın kâffesini kabul edip mucebince amel ve sebat etmediğin surette haremin talâk-l selâs ile boş olsun mu? Evet, şerâyit-i mündericenin kâffesini kabul edip mucebince amel ve sebat etmediğim surette haremim talâk-ı selâs ile boş olsun.

Ve bu kabul ve ikrardan döner isen rûz-ı mahşerde yüzün kara olsun mu? Olsun.

Ve bu ahidnamedeki şerâyitin ve erkânın kâffesini kabul edip ve mucebince amel ve sebat etmezsen İbn Mülcemliği, Şimrliği, Mervanlı̆̆l, Muaviyeliği, Yezidliği, Nemrudluğu, Firavunluğu, Ebucehilliği kabul ettin mi? Ettim.

Ve şerâit-i mezkûrede sebat etmezsen Cenâb-ı Hakk'ı ve peygamberimiz Hazret-i Muhammed sallallâhu aleyhi ve sellemi ve kâffe-i peygamberân-ı izâmı ve Hazret-i Ali kerremallâhu vechehu efendimizi ve Imam Hasan ve Imam Hüseyin efendilerimizi ve kâffe-i evlâd-ı Resûl'ü ve pîr-i destgîrimiz Hazret-i Mevlana Celâleddin Rûmîve Hazret-i Şems-i Tebrizî ve Hacı Bektaş-ı Velî efendilerimizi ve kâffe-i pîrânı inkârı kabul ettin mi? Ettim. Vallâhi mi? Vallâhi. Billâhi mi? Billâhi.

Biat eden derviş ile beraber okuyacak teslim tercümanıdır: "Erenler erkânı oldu imanım - Kalmadı gönlümde şekk ü gümânım - Takıp teslim olup Hakk'a hemîşe Erenler yolunda fedadır canım. Allah eyvallah hû dost!’”

Biat tekmil olup ayak üzerinde okunacak gülbank: "Vakt-i şerîf hayrola, hayırlar fethola, şerler defola, Allah, Muhammed, Ali, on iki imam, on dört masûm-ı pâk efendilerimiz, destgîrimiz ola, her belâda muhafaza edip görücümüz, bekçimiz ola.... Dem-i Hazret-i Mevlana, ser-i Şems ve Hacı Bektaş-ı Velî, nûr-ı nebî, kerem-i Imam Ali, hû diyelim hû." 
Rehber, sâliki getirip meydân-ı erenlerde Muhammed, Ali çerağı uyanırken rehberin okuyacă̆l gülbenk: "Muhammed, Ali, bism-i şâh Allah, eyvallah, Muhammed Ali çeră̆ı rûşân, fahr-i dervîşân, zuhûr-ı îmân, kânûn-ı merdân, ber-cemâl-i Muhammed, kemâl-i Şâh Hüseyin, gerçekler demine hû."

Revnakoğlu (283:19), Bahariye Mevlevîhanesi şeyhi Hüseyin Fahreddin Dede'nin Sütlüce Bektaşi Tekkesi şeyhi Münir Baba'dan nasip aldığını; Münir Baba'nın da talebeliğinde Nureddin şeyhi Abdülaziz Efendi'den arakiye giydiğini kaydeder. Fahreddin Dede'nin nasiplendiği Münir Baba için Revnakoğlu şu bilgileri verir (1835-36):

Hacı İbrahim Münir Baba merhum Hicrî 1251 İstanbul Galata'da doğdu. Karaağaç Bektaşî Tekkesi şeyhi Hasîb Baba'nın muhibbidir. Beyoğlu'ndaki Kör Perişan Dedebaba'dan babalık icazeti aldı. Bektaşîliğinden önce babasıyla birlikte hacca da gitti. Çok kibar, edip, kâtip bir zat olduğu söylenilir. Münirî mahlaslı nefesleri vardır. 80 yaşında göçtü. Yaşlı olmasına rağmen hafizası yerindeydi. Gayet zarif, nekregû insandı. Çok sigara ve rakı içtiği hâlde kendini bozmazdı. Tıbbiye'de okumuştur. Mühendis Mehmed Râif Paşa'nın oğludur.

\section{Uşşâkiyye'den:}

İstanbul'da Yedikule Uşşâkî Tekkesi şeyhi Emin Baba (204:91-93) ile Uşşâkîlik Bektaşî renge bürünür. Meclis-i Meşâyih reisi Muhyiddin Efendi "Bu gürûh Uşşâkîler, Dersaadet Uşşâkî meşayihi ile mugâyir-i hâl ve tabiattır.” hükmüyle Uşşâkîlerin bu kolundaki Bektaşî cihetin geçen asırda İstanbul'da temsil edildiğini tespit eder. Yine Revnakoğlu notlarında Uşşâkîler içinde bir zümre için şu notlar yer alır (186:15): "Nazilli'den gelen Hulûsî koluna mensup bir kısım yeni Uşşâkîler, Bektaşîliği benimsedikleri için pîr evi şeyhi Cemaleddin Efendi bunlara "erkân bozucu" der ve dergâha koymazdı." Revnakoğlu erkân bozuculuğa misal olarak da "Uşşâkîlerde şeyh postunun yeri mihrabın sağındadır, yalnız Denizli'den gelen kolda mihrabın içine almışlardır, bunlarda sûre-i Mülk cumhurla okunur" notunu düşer. Takipçileriyle Anadolu'da devam eden bu şube, İstanbul'da bilhassa yukarıda zikredilen Yedikule Uşşâkî Tekkesi'nde Emin Baba ile temsil edildi (204:165-66):

Nâzenîn-i Uşşâkiyye'den Fethiyeli Şeyh Hüseyin Hakk1-1 Mürebbî Baba'nın halifelerinden Tireli Mehmed Emîn Tevfîkî Efendi (Emin Baba derler) 1300'de İstanbul'a gelip bu mescide meşihat koydu ve cuma günleri Uşşâkî usulüyle zikre başladı...

Bu Bektaşî neşeyi Emin Baba halifelerinden Fahreddin Himmetî Efendi (ö.1915), İstanbul'da Aksaray'da Kırkağaçlı Emin Efendi Tekkesi'nde sürdürmüştü. Fahreddin Himmetî, UşşâkîBektaşî kolunun ilk mühim siması Ömer Hulûsî Efendi'nin (ö.1868) damadıdır.

II. Mahmud döneminde faaliyetlerine son verilen Bektaşîlik, II. Mahmud'un oğlu Abdülmecid devrinde serbest bırakılmış, bu tarihten itibaren diğer tarikatların bir kısmında, bilhassa bazı şeyhler noktainazarından tesir icra etmişti. Uşşâkîlik’te yukarıda bahsedilen şube bu cihetten 
prototiptir. Sadeddin Nüzhet Ergun, Türk Musikisi Antolojisi’nde (Ergun, II, 1943: 410), Bektaşilik ve diğer tarikatlar arasında teması tenkit diliyle anlatır:

Abdülmecid'in cülûsundan sonra Bektaşîler tekrar ortaya çıkmışlar, tekkelerine de gene babalar tayin edilmişti. Fakat diğer tarikatlar arasına evvelce sokulan Bektaşîler cahil bazı dervişlerin itikatları üzerinde müessir oldular ve birtakım Bektaşî akidelerinin tabiî dinin ve tarikatın esaslarına vâkıf olmayanlar arasına yayılmasında mühim birer amil oldular. Müritlerini namazdan niyazdan affeden, şer’̂̂ tekliflerden kurtaran birtakım şeyhlerin türemesi en ziyade bu tarihten sonradır. 19. asrın sonlarına doğru muhtelif tarikat kisveleri altında birtakım Bektaşîlere tesadüf edilmesi de bundandır. "Nâzenîn-i Uşşâkiyye" diye ayrıca bir tarikatın teessüs ettiğine de gene bu asırda tesadüf edilir. Fakat bu zümrenin Uşşâkîlik'le hiçbir münasebeti olmadığı da muhakkaktır, çünkü Halvetîlik'in bir kolu olan bu tarikatın müessisi Hüsameddin Uşşâkî tam manasıyla müteşerii ve müttaki bir mutasavvıftır...

Hangi kisveye bürünürse bürünsün, Bektaşîlerin en mühim vazifeleri halkı ve diğer tarikat mensuplarını Bektaşîlik'e meylettirmektir. Bunlar, "Feyz ancak Bektaşîlik'tedir, diğer tarikatlar bundan mahrumdur. İnsan Bektaşî olmadıkça "Ehl-i Beyt" muhibbi olamaz. Bektaşîlik'in ibtidası, diğer tarikatların intihasıdır" gibi muayyen tabirlerle birtakım insanları kendi tarikatlarına celbetmeye çalışmışlardır.

Hüseyin Vassâf, kendisi Uşşâkîlik’ten hilâfetli ve müteşerri olmakla beraber, Uşşâkîlik içinde Bektaşî hâlli yapılanmanın bilhassa Câhidiyye kolundan çıkan Muslihiyye'de görüldüğünü, Çanakkale havalisinde bu tür bir neşenin Uşşâkîlik'e tesir ettiğine Sefine-i Evliyâ' da yer verir. Aynı kalem, yukarıda bahsi geçen Nâzenîn-i Uşşâkiyye'den Emin Baba'nın Bektaşîlik'ini tevil yoluna gider, onun için Sefine’ de (Vassaf, IV, 2006: 475) şunları söyler:

Nice Bektaşîleri kendisi Bektaşî görünerek yolundan çeler, tarîk-i Uşşâkî̀ye döndürürdü. Bilmeyenler ona "Bektaş̂̂"dir derlerdi. Bir nutkunda li-hikmetin Bektaşîlik'i bile medhetmişti, hâlbuki onun medhi bir siyâset-i tarîkat idi, yoksa Muhammediyyü'l-meşreb sünniyyü'l-mezheb idi.

\section{Nakşibendiyye-i Hâlidiyye'den:}

Revnakoğlu görüntüsü ve belli davranışları ile şaşılacak derecede Alevîmeşrep olduğunu söylediği Şeyh Mustafa Efendi hakkında şunları aktarmaktadır (205:398-402):

Selânik Kara Müftü Tekkesi şeyhi Haşmet Efendizâde Şeyh Mustafa Efendi, Muhammed Can el-Mekkî halifelerinden, Selanik Meclis-i Meşâyih reisi ve İki Lüle şeyhi Hacı Ali Efendi'nin halifesidir. Kendisi Nakşî - Hâlidî olduğu hâlde şaşılacak şekilde Alevîmeşrepti, bıyıklarını kesmezdi, matem aylarında Muharrem'de Safer'e kadar oruca girer, geceleri de ağzına su koymazdı. Tekkede mukabele günleri cehrî olarak zikrettirir ve ayağa kalkardı. İstanbul'da Üsküdar'da vefat eyledi. Halifesi Şeyh Abdullah Efendi, Eyüp'te Nakşibendiyye'den Vezir Tekkesi'ne şeyh oldu. 


\section{SONUÇ}

Cemalettin Server Revnakoğlu'nun Süleymaniye Kütüphanesi’nde bulunan kişisel arşivi pek çok alandan yığınla vesikayı ihtiva etmektedir. Özellikle İstanbul tasavvuf tarihi hakkındaki bilgilerde derinlik ve konuya hakimiyet dikkat çekmektedir.

Kendisi Bektaşi olmasa da İstanbul'daki Bektaşi dergahlarını, mütevazı zaviyelerini şeyhleri ve halifeleri ile çoğu zaman kendi şahitliğine dayanan bilgilerle anlatmıştır. Revnakoğlu arşivinden beş Bektaşi şeyhinin biyografisi bu çalışmada anlatılmıştır. Bu şeyhler hakkında verilen ayrıntılı bilgi dikkat çekmektedir. Sütlüce Bektaşî Tekkesi şeyhi Münir Baba'nın muhibbi olan ve babalık icazetnamesini Hacı Feyzullah Dedebaba'dan alan İbrahim Baba hem resmî biyografisiyle anlatılmış hem de kılık kıyafetinden karakter özelliklerine kadar her yönüyle yansıtılmıştır. Revnakoğlu özellikle Tevfik Baba’yı anlatırken hakkında söylenen dedikodular, nükteler, Bektaşî babalığı hakkında latifeler de dahil olmak üzere hemen her şeyi kaydetmiştir. Babalık icazetnamesini Nafi' Baba'dan alan bu şahsiyet Şahkulu Sultan Dergâhı'nın son resmî şeyhidir. Siyasi tarafı biraz karışıktır, İslam masonları denilen Tarikât-ı Salâhiyye'ye mensup olmasına rağmen milli hükümet için gösterdiği faydalar neticesinde istiklal madalyası almıştır.

Çamlıca Bektaşî Tekkesi postnişini Ali Nutki Baba'dan babalık icazetnamesi alıp Kapalıçarşı ve Üsküdar'da Bektaşilliği yaymış olan Hasan Basri Baba, Âşık Paşa ve Lutfî Efendi tarihlerinin haşiyeleri başta olmak üzere pek çok eserde hizmeti bulunmasına rağmen sahasında çok sessiz olduğu için pek tanınmayan Bektaşi Âlî Bey, Revnakoğlu'nun anlattığı diğer kişilerdir. Nutkî Baba'dan icazetname almış olan Ali Fethi Beybaba ise çocukluk mahcubiyetini korumuş, asla tarikattan çıkar sağlamayan biri olarak Revnakoğlu'nun takdirle andığı kişilerdendir.

İstanbul'da Rifâ‘iyye tarikatında Bektaşî cihetin Üsküdar Rifâ‘i asitanesinde Ziya Baba, Kubbeli Tekke'de Molla Bey ile temsil edildiği anlaşılmaktadır. Döneminde Bektaşîliği dolayısıyla eleştirilen Ziya Baba'yı Revnakoğlu karakterinden görünüşüne kadar ince ayrıntısı ile yansıtmaktadır. Molla Bey ise yetiştirdiği halifelerinin çokluğuyla nüfuzunu ortaya koymaktadır.

Celvetiyye'de Bektaşîleşme ise diğer tarikatlardan daha erken bir dönemde başlamıştır. Bektaşîliğe karşı sert bir tavrı olan Celvetiler Haşim Baba'ya bu tercihinin bedelini ödetmiştir. Haşim Baba öldügünde cenaze namazı kılınmak için Celvetiyye asitanesine getirilmiş ancak Bektaşî olduğu için içeriye alınmayıp cenazesi cümle kapısına yakın bir yerde kılınmıştır. Sonra burası Haşimiyye musallası olarak isimlendirilmiştir.

Halvetilik’te Bektaşî cihet Ramiz Dede ile karşımıza çıkmaktadır. Revnakoğlu'nun, her halini iyi bilirim dediği Ramiz Dede hakkında aktardığg şahsi malumat özellikle dikkat çekicidir. Bektaşîlikte babalık mertebesine erişmiş olan bu şahsiyeti ilim irfan sahibi, erişilmez meziyetlere sahip olarak zikredip iyi tanımadığı pek çok kişiye icazetname vermesini ise affolunmaz bir hata olarak değerlendirmektedir. 
Mevleviyye'de Bektaşî rengi en yoğun aksettiren şahsiyet Abdülvahid Çelebi idi, ayrıca Bahariye Mevlevihanesi şeyhi Hüseyin Fahreddin Dede, Sütlüce Bektaşî Tekkesi şeyhi Münir Baba'dan nasip almıştı. Revnakoğlu, Bektaşiyye'den hilafet alıp nasip veren Abdülvahid Çelebi'yi dikkat çekici yönleri ile nakletmiştir. Hürriyetperver zevata yardım ettiği için saray tarafından sevilmeyen Abdülvahid Çelebi'nin kimi Bektaşîler tarafından da sevilmediğini aktaran Revnakoğlu, Bektaşiyye içindeki kıskançlıklara da değinmektedir. Abdülvahid Çelebi’nin Bektaşî ikrarına ait uzun bir vesikanın sureti Revnakoğlu arşivinde yer almaktadır. Bu vesika özellikle günlük yaşama ve Muharrem gibi özel bazı günlere dair pek çok folklorik malzemeyi, inanç ve uygulamaları yansıtmaktadır.

Uş̧̧akiyye'yi Bektaşî renge büründüren Yedikule Uşşakî Tekkesi şeyhi Emin Baba'dır ve çeşitli uygulamaları ile erkan bozucu olarak nitelendirilen bir kola mensuptur. Uşşakiyye içinde Bektaşî neşeyi kendisinden sonra halifesi Fahreddin Himmeti Efendi devam ettirmiştir.

Şiilik ve Alevilik temayülünün en az olduğu tarikat olarak bilinen Nakşibendiyye'nin Halidiyye kolunda Şeyh Mustafa Efendi bıyıklarını uzatması, Muharrem orucu tutması, geceleri su içmemesi gibi halleriyle Alevimeşrep bir Halidî şeyhi olarak karşımıza çıkmaktadır. Revnakoğlu bunu şaşılacak bir durum olarak zikretmektedir.

İstanbul tekkeleri tarihine dair çalışmalar yaparken Bektaşîliğe dair malumatı da tespit eden Revnakoğlu'nun arşivinde yer alan bütün bu vesikalar İstanbul tekkeler tarihinin son dönemlerine ait bilgilerin unutulmasını, kaybolmasını engellemiştir.

\footnotetext{
Hakem Değerlendirmesi: Dış bağımsız.

Çıkar Çatışması: Yazar çıkar çatışması bildirmemiştir.

Finansal Destek: Yazar bu çalışma için finansal destek almadığını beyan etmişstir.
}

Peer-review: Externally peer-reviewed.

Conflict of Interest: The author has no conflict of interest to declare.

Grant Support: The author declared that this study has received no financial support.

\section{KAYNAKÇA/REFERENCES}

Ergun, S. N. (1943). Türk Musikisi Antolojisi (Cilt 2) Dini Eserler. İstanbul: Rıza Koşkun Matbaası, s. 410. Osmânzâde Hüseyin Vassaf. (2006). Sefîne-i Evliyâ (Cilt 1). (M. Akkuş, A. Yı1maz, Haz.) İstanbul: Kitabevi Osmânzâde Hüseyin Vassâf. (2006). Sefîne-i Evliyâ (Cilt IV). (M. Akkuş, A. Yılmaz, Haz.) İstanbul:Kitabevi. Revnakoğlu, C. S. (1952, 22 Ekim). Bektaşîlikte Dinî Bir Ayin Var mı?, Vakit.

Revnakoğlu, C. S. (1965). Meşhur Bektaşiler: Yaşar Baba. Tarih Dünyası, (Cilt 2). (S. 6). s-s. 177-180.

Revnakoğlu, C. S. (1965). Meşhur Bektaşiler: Yaşar Baba. Tarih Dünyası, (Cilt 2). (S. 7). s-s. 251-253. 
